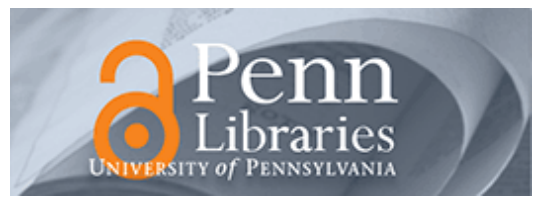

University of Pennsylvania

ScholarlyCommons

Management Papers

Wharton Faculty Research

2012

\title{
Learning Versus Stealing: How Important Are Market-Share Reallocations to India's Productivity Growth?
}

Ann E. Harrison

University of Pennsylvania

Leslie A. Martin

Shanthi Nataraj

Follow this and additional works at: https://repository.upenn.edu/mgmt_papers

Part of the Advertising and Promotion Management Commons

\section{Recommended Citation}

Harrison, A. E., Martin, L. A., \& Nataraj, S. (2012). Learning Versus Stealing: How Important Are MarketShare Reallocations to India's Productivity Growth?. The World Bank Economic Review, http://dx.doi.org/ 10.1093/wber/lhs029

This paper is posted at ScholarlyCommons. https://repository.upenn.edu/mgmt_papers/90

For more information, please contact repository@pobox.upenn.edu. 


\title{
Learning Versus Stealing: How Important Are Market-Share Reallocations to India's Productivity Growth?
}

\author{
Abstract \\ Recent trade theory emphasizes the role of market-share reallocations across firms ("stealing") in driving \\ productivity growth, whereas previous literature focused on average productivity improvements \\ ("learning"). We use comprehensive, firm-level data from India's organized manufacturing sector to show \\ that market-share reallocations were briefly relevant to explain aggregate productivity gains following the \\ beginning of India's trade reforms in 1991. However, aggregate productivity gains during the period from \\ 1985 to 2004 were largely driven by improvements in average productivity. We show that India's trade, FDI, \\ and licensing reforms are not associated with productivity gains stemming from market share \\ reallocations. Instead, we find that most of the productivity improvements in Indian manufacturing \\ occurred through "learning" and that this learning was linked to the reforms. In the Indian case, the \\ evidence rejects the notion that market share reallocations are the mechanism through which trade \\ reform increases aggregate productivity. Although a plausible response would be that India's labor laws \\ do not easily permit market share reallocations, we show that restrictions on labor mobility cannot \\ explain our results.

\section{Disciplines} \\ Advertising and Promotion Management
}




\title{
Policy Research Working Paper 5761
}

\section{Learning versus Stealing How Important are Market-Share}

\author{
Reallocations to India’s Productivity Growth?
}

\author{
Ann E. Harrison \\ Leslie A. Martin \\ Shanthi Nataraj
}

The World Bank

Development Economics Vice Presidency

August 2011 
Policy Research Working Paper 5761

\section{Abstract}

Recent trade theory emphasizes the role of marketshare reallocations across firms ("stealing") in driving productivity growth, while the older literature focused on average productivity improvements ("learning"). The authors use comprehensive, firm-level data from India's organized manufacturing sector to show that market-share reallocations did play an important role in

aggregate productivity gains immediately following the start of India's trade reforms in 1991. However, aggregate productivity gains during the overall period from 1985 to 2004 were driven largely by improvements in average productivity, which can be attributed to India's trade liberalization and FDI reforms.

This paper is a product of the Development Economics Vice Presidency. It is part of a larger effort by the World Bank to provide open access to its research and make a contribution to development policy discussions around the world. Policy Research Working Papers are also posted on the Web at http://econ.worldbank.org. The authors may be contacted at mhaddad@worldbank.org, ann.harrison@berkeley.edu.

The Policy Research Working Paper Series disseminates the findings of work in progress to encourage the exchange of ideas about development issues. An objective of the series is to get the findings out quickly, even if the presentations are less than fully polished. The papers carry the names of the authors and should be cited accordingly. The findings, interpretations, and conclusions expressed in this paper are entirely those of the authors. They do not necessarily represent the views of the International Bank for Reconstruction and Development/World Bank and its affiliated organizations, or those of the Executive Directors of the World Bank or the governments they represent. 


\title{
Learning versus Stealing: How Important are Market-Share
}

\author{
Reallocations to India's Productivity Growth?*
}

\author{
Ann E. Harrison, Leslie A. Martin and Shanthi Nataraj ${ }^{\S}$
}

${ }^{*}$ We thank Mr. M.L. Philip, Mr. P.C.Nirala, Dr. Praveen Shukla, and Mr. M.M.Hasija at the Ministry of Statistics and Programme Implementation for their assistance in understanding the Annual Survey of Industries data collection process; Rana Hasan, Karl Jandoc, and Steve O'Connell for discussions regarding the firm-level data; and Pauline Grosjean and Ben Crost for providing us with their district-level concordances, which formed a basis for ours. This material is based upon work supported by the National Science Foundation under Grant No. 0922332. Any opinions, findings, and conclusions or recommendations expressed in this material are those of the authors and do not necessarily reflect the views of the National Science Foundation.

${ }^{\dagger}$ Department of Agricultural and Resource Economics, University of California, Berkeley, and NBER.

${ }^{\ddagger}$ Department of Agricultural and Resource Economics, University of California, Berkeley.

${ }^{\S}$ RAND Corporation. 


\section{Introduction}

Recent trade theory stresses the importance of market-share reallocations in increasing aggregate productivity following a trade liberalization (Bernard, Eaton, Jensen and Kortum 2003, Melitz 2003). In contrast, the earlier literature emphasized the idea that trade could improve average productivity among existing firms (Corden 1974, Grossman and Helpman 1991, Helpman and Krugman 1985, for example). Yet there are few empirical studies that quantify the relative importance of average productivity gains versus gains from market-share reallocations in the wake of a major trade liberalization.

In this paper, we use a comprehensive, firm-level dataset that allows us to examine the role played by market-share reallocations in aggregate productivity growth in India's organized manufacturing sector from 1985 to 2004. ${ }^{1}$ In 1991, India embarked on a series of reforms, including a major trade liberalization. We confirm that for the organized manufacturing sector as a whole, market-share reallocations were an important source of productivity growth in the years immediately following the start of the 1991 reforms, but not during other periods.

We document three distinct phases in India's manufacturing productivity during the period from 1985 to 2004. During this time, aggregate productivity (defined as output-weighted, mean firm productivity) grew by nearly 20\%. From 1985 to 1990, the growth in aggregate productivity was driven by "learning" - that is, an increase in unweighted, average firm productivity. This measure of learning captures the change in productivity for the average firm, and therefore includes not only changes in productivity among surviving firms, but also changes in average productivity that can be attributed to firm entry and exit. In the period immediately following the start of the reforms (1991-1994), the "stealing" of market share - that is, the reallocation of market share from less productive to more productive firms - became more important than learning in driving aggregate productivity growth. In the longer run (1998-2004), learning once again became the more important factor in aggregate productivity growth, with stealing (reallocation) contributing

\footnotetext{
${ }^{1}$ The organized (formal) manufacturing sector in India consists of firms that are registered under Sections $2 \mathrm{~m}(\mathrm{i})$ and $2 \mathrm{~m}$ (ii) of the Factories Act; all firms with 20 or more employees (10 if power is used) are required to register. The organized sector accounts for approximately $80 \%$ of manufacturing sector output, though only $20 \%$ of employment.
} 
little. During the 20-year period from 1985 to 2004 as a whole, most of the increase in aggregate productivity can be explained by improvements in average productivity.

Our main results rely on the widely-used decomposition suggested by Olley and Pakes (1996), hereafter referred to as OP. This method identifies changes in average productivity and reallocation, but does not disentangle the contributions of survivors, entrants, and exiters. Although firm identifiers are not available for the organized sector data during most of the time period we study, we have also constructed a panel dataset by matching individual firms from one year of the survey to the next. This panel allows us to test how our main results change when we employ an alternative decomposition method, suggested by Melitz and Polanec (2010), hereafter referred to as MP. Applying the MP method allows us to separate productivity changes among survivors from changes among entering and exiting firms; however, it requires an accurate identification of entry and exit. We are fairly confident about identifying entrants, but given the nature of the panel, exiters are less well-identified. When we apply plausible assumptions regarding exit to our panel, the MP decomposition yields a similar story as our baseline findings. However, we also illustrate that the results of the MP decomposition depend on the specific assumptions on exit. While the MP method yields richer results than the OP method, our results suggest that researchers working with panel datasets in which entry and exit are not well-identified should remain cautious about applying decomposition methods that depend on accurately distinguishing entrants and exiters.

We then use the OP decomposition to examine the extent to which individual policy reforms are associated with industry-level productivity gains. In particular, we exploit variations in tariff cuts, foreign direct investment (FDI) liberalization, and industrial licensing reforms across industries to examine the contribution of each reform to changes in industry-level TFP. We find that the average decline in final goods tariffs during this time period implies a $3.2 \%$ increase in aggregate productivity, while the average decline in input tariffs implies a nearly $22 \%$ increase in aggregate and average productivity. Moreover, the FDI liberalization also accounts for a $2.1 \%$ increase in aggregate productivity, and a $4.6 \%$ increase in average productivity. The industrial licensing reforms, which promoted internal competition, are associated with productivity gains among large 
firms, and in states and industries that were relatively less exposed to external competition (through proximity to ports and trade exposure) prior to the reforms.

Finally, we use our panel dataset to isolate the impacts of the policy changes on within-firm changes in productivity. Once we control for time-invariant, firm-specific characteristics, the magnitude of the policy impacts is somewhat attenuated, suggesting that the changing composition of firms, and unobservable, firm-level characteristics, may play important roles in determining productivity growth. Nonetheless, our findings confirm that the trade and FDI liberalizations are associated with increased within-firm productivity.

Our study was motivated by the emphasis that the new trade theory places on the importance of market-share reallocations in increasing aggregate productivity. Although a number of papers have tested various implications of this literature (see, for example, Arkolakis (2010), Bernard et al. (2003), Bernard, Jensen and Schott (2006), Berthou and Fontagne (2010), Eaton, Kortum and Kramarz (2008), Helpman, Melitz and Yeaple (2004), Manova and Zhang (2010)), few are able to directly test the effect of a trade liberalization episode on market-share reallocations, and existing evidence on the role of reallocation is mixed. For example, Tybout and Westbrook (1995) find that the reallocation of market share to relatively low-cost firms explained little of the overall change in productivity following Mexico's trade liberalization; however, Pavcnik (2002) and Menezes-Filho and Muendler (2007) find that market-share reallocation was an important driver of productivity growth following trade reforms in Chile and Brazil, respectively. Trefler (2004) documents that a fall in Canadian tariffs increased industry-level labor productivity, but not within-plant labor productivity, which he interprets as evidence that reallocation was more important than withinplant improvements. In Colombia, Fernandes (2007) finds that average productivity gains were more important than reallocation, but that reallocation became important in many industries during periods of tariff liberalization.

Our study also contributes to the substantial body of work examining India's 1991 reforms. Topalova and Khandelwal (forthcoming) establish that the reductions in final goods and input tariffs increased productivity among approximately 4,000 large, publicly listed manufacturing firms. 
Sivadasan (2009) uses a dataset that is similar to ours for the early years of the reforms (1986-1994) and finds that the reduction in final goods tariffs and the FDI liberalization increased productivity. He also documents that these reforms were linked with average productivity increases, but not reallocation, in the early 1990's. Nataraj (2010) compares the reactions of the organized and unorganized manufacturing sectors to trade liberalization, and finds that while the reduction in final goods tariffs increased productivity significantly in the unorganized sector, the reduction in input tariffs was more important for productivity growth in the organized sector. Aghion, Burgess, Redding and Zilibotti (2008) find that following the removal of licensing requirements, the number of factories and output in the organized sector increased, particularly in states with relatively less restrictive labor regulations.

Our study contributes to these two strands of literature in several ways. First, we document that market-share reallocations were important to overall productivity growth immediately following the start of the 1991 reforms, while average productivity gains were more important during the periods from 1985-1990 and 1998-2004. Second, we show that the trade and FDI liberalizations explain a substantial amount of overall productivity growth. Third, we construct a panel that represents a large share of the organized manufacturing sector and spans the period from 1985 to 2004. We use the panel to explore a new decomposition method that disentangles the contributions of surviving, entering and exiting firms to overall productivity growth. We illustrate that this method can provide a richer set of results, but that the results are very sensitive to the correct treatment of exit. Our findings indicate that researchers working with panel datasets in which entry and exit are not well-identified should be cautious when applying this type of decomposition. Finally, we also use the panel to confirm that the trade and FDI reforms contributed substantially to average, within-firm productivity growth.

The rest of this paper is organized as follows. Section 2 provides a brief background on the Indian reforms; Section 3 describes the data and outlines the construction of the panel of firms; Section 4 discusses the empirical framework and presents results; and Section 5 concludes. 


\section{The 1991 Reforms}

Prior to 1991, India had a highly restrictive trade regime, with average final goods tariffs on manufactured products of approximately 95\%, as well as non-tariff barriers on most goods. FDI was capped at $40 \%$ for most industries, and large manufacturing firms were required to obtain operating licenses. During the 1980s, India began to liberalize its licensing policies to some extent, removing industrial licensing requirements from approximately one-third of industries; however, trade and FDI restrictions remained in place. India's fiscal deficit continued to grow during this time, as did its balance of payments deficit.

In 1991, a combination of economic and political shocks - namely, a rise in oil prices, a decrease in remittances and lower demand from abroad, and an unstable political climate - created a balance of payments crisis (Topalova and Khandelwal forthcoming). A new government requested help from the IMF, which was granted on the condition that India undertake several reforms (Hasan, Mitra and Ramaswamy 2007). In July 1991, the government announced a series of major policy changes, including FDI liberalization, exchange rate liberalization, the removal of the requirement for operating licenses in most industries, the removal of import licensing requirements for capital and intermediate goods, and a reduction and harmonization of tariffs across industries. Many of these policy changes were formalized in India's Eighth Five-Year Plan (1992-97).

Between 1991 and 1997, the average final goods tariff rate on manufactured products fell from 95\% to $35 \%$ (Panel (a) of Figure 1). Not only did average tariffs fall, but tariffs were also harmonized across industries; therefore, the industries with the highest pre-reform tariffs faced the highest tariff cuts. Panel (b) of Figure 1 shows a negative, linear relationship between an industry's pre-reform tariff level and the change in tariffs through 1997. After the Eighth Five-Year Plan (post-1997), India continued to lower its tariffs, though the reductions were no longer as uniform. Panel (a) of Figure 1 shows that some tariffs were even increased during this time. Panel (c) of the same figure indicates that if we compare tariff changes through 2004 with pre-reform tariffs, the negative relationship exhibited through 1997 still holds, although there are a few more outliers.

In addition to final goods tariffs, we also consider the impact of input tariffs on productivity. 
We calculate input tariffs using India's Input-Output Transactions Table, following the method suggested by Amiti and Konings (2007). For example, if the footwear industry derives $80 \%$ of its inputs from the leather industry and $20 \%$ from the textile industry, then the input tariff for the footwear industry is 0.8 times the final goods tariff for the leather industry plus 0.2 times the final goods tariff for the textile industry. In our baseline measure of input tariffs, we use both traded and non-traded inputs, assigning tariff rates of zero to non-traded inputs. ${ }^{2}$

One potential concern with including input tariffs in our empirical analysis is that final goods and input tariffs may be highly correlated, thus leading to multicollinearity problems in estimation. Panel (d) of Figure 1 shows the relationship between the change in final goods tariffs and the change in input tariffs for a given industry. Though the two measures are related, there are a number of industries that received relatively large reductions in final goods tariffs but relatively small reductions in input tariffs, and vice versa. Moreover, the overall correlation coefficient between final goods and input tariffs (across years and industries) is 0.7 . Within years, the correlation coefficient is even lower (less than 0.5 in all years), which suggests that multicollinearity is not likely to be a significant problem.

We also consider two other policy changes that occurred during this period: the removal of industrial licensing requirements and the allowance of FDI into most industries without case-by-case approval. Until the 1980s, India's "license raj" required every firm with more than 50 employees (100 employees without power) and a certain amount of assets to obtain an operating license. The license specified, among other things, the amount of output a firm could produce, the types of goods it could make, and its location. In 1985, approximately one-third of industries were "delicensed" (the requirement for a license was dropped); in 1991, most industries were delicensed as part of the broader reforms package (Aghion et al. 2008). The restrictions on foreign investment were also liberalized during the 1990's. Prior to 1991, FDI was capped at 40\% for most industries; beginning in 1991, FDI inflows of up to $51 \%$ were allowed in selected industries with "automatic" approval (Sivadasan 2009).

\footnotetext{
${ }^{2}$ In Appendix A, we present results from an alternative measure of input tariffs that considers only manufacturing sector inputs.
} 
By the end of 1991, nearly $85 \%$ of industries had been delicensed. The licensing requirement was removed from several additional industries in subsequent years, and by the end of the 1990's, over $90 \%$ of industries had been delicensed. In contrast, the FDI liberalization occurred somewhat more slowly: only one-third of industries were FDI liberalized in 1991. A few additional industries were liberalized by 1997, but it was not until 2000 that the government indicated that all industries would be eligible for automatic FDI approval, except those requiring an industrial license or meeting several other conditions. Table 1 shows the evolution of the reforms over time.

The fact that most of these policy changes occurred as part of an externally-required reforms package lowers the chance that industries were selected into the reforms based on political factors. In addition, to the extent that industries with certain characteristics may have been more likely to be liberalized, we use a fixed-effects estimation strategy that should address any timeinvariant characteristics that could have affected selection. However, if the reforms are correlated with pre-reform trends in industry characteristics, then our results may be biased. To evaluate the potential extent of this bias, we examine the correlations between changes in reforms (1990-2004) and pre-reform trends in industry characteristics (1985-1989). We follow Topalova and Khandelwal (forthcoming) and consider a number of industry characteristics including wage, share of production workers, capital-labor ratio, total employment and output, and firm size (average employment). We also consider pre-reform trends in total factor productivity (TFP). Table 2 indicates that there are no statistically significant correlations between pre-reform trends in industry characteristics and future reforms. Moreover, in Appendix A we show that our results are robust to limiting our analysis to the period through 1997; since these initial reforms were largely carried out as outlined in the Eighth Five-Year Plan, which was developed in the wake of the 1991 crisis, they are even less likely to be subject to potential selection issues than reforms in later years. 


\section{Data}

\subsection{Annual Survey of Industries (ASI) Data}

Our primary dataset consists of firm-level surveys from the Annual Survey of Industries (ASI). The period of coverage for each ASI survey is the accounting year that ended on any day during the fiscal year: the 1985-86 survey (which we refer to as the 1985 survey) refers to the factory's accounting year that ended on any day between April 1, 1985 and March 31, 1986. We obtained firm-level data for all available years between 1985 and 2004. Data were not available for 1995. In addition, the way in which input data were collected and made available for the years 1996 and 1997 did not make it possible to construct certain key variables for those two years that were consistent with the other years. Therefore, we restrict our analysis to the firm-level data for the remaining 17 years between 1985 and 2004 (1985 through 1994 and 1998 through 2004).

The sampling universe for the ASI is all firms that are registered under Sections 2m(i) and 2m(ii) of the Factories Act, as well as firms registered under the Bidi \& Cigar Workers Act, and a number of utility and service providers. We include only manufacturing firms in our analysis. All firms that have 20 or more employees (10 or more employees if a power source is used) are required to register. ${ }^{3}$ The sampling frame is derived from the registry list of each state's Chief Inspector of Factories, and all but four small states are covered.

The ASI divides firms into two sectors - the "census" sector, in which firms are surveyed every year, and the "sample" sector, in which firms are sampled every few years. Between 1985 and 2004, the inclusion of firms in the census and sample sectors, as well as the sampling strategy, changed several times. To ensure that our results are representative of the population of firms, we apply the sampling multiplier weights that are provided for each firm in the population analysis (but not the panel analysis).

Each unit surveyed is generally a factory; however, if an owner has two factories in the same

\footnotetext{
${ }^{3}$ Although firms with fewer than 10 employees are not required to register under this act, and therefore should not appear in the sampling universe, a significant fraction of firms report fewer than 10 employees. These firms may be registered for various reasons, including the possibility that they used to have more than 10 employees but shrank; that they plan to grow in the future; and that registering may be a signal to creditors or other business partners.
} 
state, sector (census versus sample) and industry, a joint return can be furnished. In the population of firms, fewer than $2 \%$ of the observations report more than one factory, and we will use the term "firm" to mean one observation in our dataset.

The key variables we construct from the ASI data are output, material input, labor, and capital. ${ }^{4}$ We drop closed firms from the dataset, and we include only firms with positive values of the key variables. To address a few extreme outliers, we also trim the top $0.5 \%$ of output and material input values.

We deflate output using industry-specific wholesale price indices (WPI) from the Government of India's Handbook of Industrial Statistics. Similarly, our material input measures are deflated by constructing deflators using the WPI along with India's 1993-94 Input-Output Transactions Table. Labor is measured as the total number of people employed by the firm, and capital is measured by deflating the book value of capital by the WPI for machinery. ${ }^{5}$

Summary statistics for the population are presented in Table 3. Only open firms that have positive values of our key variables are included. Sampling weights are applied to the summary statistics in the first column, so the results are representative of the overall organized sector. The second column shows results for the firms that were sampled, without applying sampling weights. Since larger firms are surveyed more often than smaller firms, the mean and median values of output, capital, material inputs, and labor are much larger in the sampled population rather than the estimated population.

\subsection{Creating a Panel}

The ASI data provide unique firm identifiers beginning in 1998. However, it has not previously been possible to track firms prior to 1998 , and thus to follow them during the most significant period of reforms. We overcome this challenge by matching individual firms from one year of

\footnotetext{
${ }^{4}$ Output includes the ex-factory value of products, the increase in the stock of semi-finished goods, and the value of own construction; material input includes material and fuel.

${ }^{5}$ In Appendix A, we show that our results are robust to measuring capital using the perpetual inventory method described in Harrison (1994), as modified by Sivadasan (2009).
} 
the survey to the next between 1985 and 1998. We then combine this constructed panel with the pre-formed panel provided by the ASI from 1998-2004.

We construct our panel as follows. First we pair firms that appear in consecutive years. We search for exact duplicates in Open and Close values between one year and the next (e.g. we look for a match between the Close value in 1985 and the Open value in 1986) in one of the following six variables: stock of raw materials, fuels, and stores; stock of semi-finished goods; stock of finished goods; inventory; loans; and fixed capital. We identify all exact non-zero matches in Open and Close variables and count the number of digits in each match excluding trailing zeros; we then match every pair of firms that has at least six digits of exact matches. ${ }^{6}$ In the case of conflicting firm matches, we take the pair that matches the largest number of digits over the six variables. On average, matched firms have 24 non-trailing-zero digits in common. We apply this technique from 1985-1994 and from 1996-1998. ${ }^{7}$

Second, we attempt to link firms over 1995, a year for which firm-level data have not been released, and over other years in which individual firms may not have been sampled. In this step, we consider matches within state, 2-digit industry code, and permanent serial number. Though the ASI provides a permanent serial number for each firm, this number is not unique; however, excluding two periods in which permanent serial numbers appear to have changed, permanent serial numbers are equal across known matches more than $90 \%$ of the time. We therefore use the permanent serial number along with state and 2-digit industry codes to bridge gap years. We validate any observations matched in this manner by requiring that they match on at least five of the following six variables: year of initial production, district, ownership, 3-digit industry and growth in labor and fixed capital. ${ }^{8}$

\footnotetext{
${ }^{6}$ For example, two firms that report 10000 rupees of fixed capital would match 1 digit for this variable. Two firms that report 10003 rupees of fixed capital are credited for 5 digits. However, two firms that report 10002 and 10003 rupees, respectively, receive no credit (though could be matched based on other variables or in subsequent steps).

${ }^{7}$ As discussed above, we do not construct TFP directly from the firm-level data in 1996 and 1997 given the way in which several inputs were reported in those years. However, we are able to perform the matching procedure using the variables listed above, and we impute TFP for these years as discussed below.

${ }^{8}$ The mapping of district codes to geographical regions changes frequently over the period of our survey, so we generate a concordance of district codes over time, using existing concordances as well as the changing codes observed in our known panel matches. We thank Pauline Grosjean and Ben Crost for providing us with their district code concordance, which formed a basis for ours.
} 
For the growth in labor and fixed capital, we use known matches from the first step to establish confidence intervals for subsequent period values as a function of the number of years elapsed between observations. We break each variable into 500-unit increments, and require potential matches in non-adjacent years to fall within a 5th degree polynomial fit of the 10th and 90th percentiles of observed growth or decline in that variable. Based on our analysis of the pre-formed panel, we allow for variation of up to two years in the stated year of initial production. Conflicting matches are resolved by taking the match with the largest number of successfully matched variables. $^{9}$

Because we observe each firm's year of initial production, we are confident that we can correctly identify survivors and entrants in our panel. However, given the substantial fraction of firms that are not surveyed every year, we are more reserved about our ability to identify exiting firms. The rates of exit that we observe in our panel are significantly higher than the rates that we extrapolate from the change over time of the distribution of years of initial production. Therefore in estimating productivity we avoid methods that rely on accurately identifying firm exit, and instead employ an index number method that is robust to potentially spurious exit. However, in Section 4.3, we explore how different assumptions about exiting firms could affect our productivity decomposition results, and in Section 4.5, we exploit the fact that we can confidently identify surviving firms to examine the impacts of the reforms on within-firm learning.

Summary statistics for the panel (to which we do not apply sampling multipliers) are presented in the final column of Table 3. Larger firms (those that are in the "census" sector and are surveyed every year) make up more than $60 \%$ of the firm-year observations in the panel, $45 \%$ of firm-year observations in the full sample of firms, and only $20 \%$ of firm-year observations in the estimated population. The panel should not be seen as representative of the population, but rather as a selection of relatively large firms. Nonetheless, the bottom rows in Table 3 show that $71 \%$ of firm-year observations that appear in the sample, representing 93\% of total deflated output over

\footnotetext{
${ }^{9}$ The pre-formed 1998-2004 panel dataset does not contain similar permanent serial numbers or district identifiers, but we also have an older, cross-sectional dataset, which does have permanent serial numbers and district codes, covering the same years. We merge permanent serial numbers and district identifiers into the pre-formed panel dataset using a sample of common variables.
} 
the entire period and $92 \%$ of the labor force, are captured for at least two years in the panel.

\subsection{Policy Variables}

The four policies we consider - final goods tariffs, input tariffs, delicensing, and FDI reform - were discussed in Section 2. Our tariff data are based on the Government of India's Customs Tariff Working Schedules and the Trade Analysis and Information System (TRAINS) database. Both sources provide rates for approximately 5,000 harmonized system (HS) product codes. Using the concordance of Debroy and Santhanam (1993), we match the product lines with 3-digit NIC-87 codes, and calculate average final goods tariff rates within each of approximately 140 industries. ${ }^{10}$ We calculate input tariffs as described in Section 2.

To capture the effects of the delicensing reforms, we use data from Aghion et al. (2008) from 1985 to 1997 , supplemented by information from Press Notes from the Ministry of Commerce \& Industry from 1998 to 2004 . The delicensing variable is a dummy that takes on a value of one if any products in a three-digit industry have been delicensed, zero otherwise. Our measure of FDI liberalization is also based on Press Notes from the Ministry of Commerce \& Industry, and takes on a value of one if any products in a three-digit industry have been liberalized, zero otherwise. Table 1 shows changes in these policy variables over time.

\section{Empirical Framework and Results}

\subsection{Measuring Total Factor Productivity}

We measure TFP for firm $i$ in industry $j$ at time $t$ using a chain-linked, index number method suggested by Aw, Chen and Roberts (2001):

\footnotetext{
${ }^{10}$ Prior to 1986, tariff data were reported in Brussels Tariff Nomenclature (BTN) rather than HS codes. For these years, we first map BTN codes to HS codes using a concordance table from the TRAINS database.
} 


$$
\begin{aligned}
& T F P_{i j t}=\underbrace{\left(q_{i j t}-\overline{q_{j t}}\right)}_{\text {deviation fromavg.q }}+\underbrace{\sum_{r=2}^{t}\left(\overline{q_{j r}}-\overline{q_{j r}-1}\right)}_{\text {yearlychangein } q} \\
& -[\underbrace{\sum_{z=1}^{Z} \frac{1}{2}\left(\zeta_{i j t}^{z}+\overline{\zeta_{j t}^{z}}\right)\left(z_{i j t}-\overline{z_{j t}}\right)}_{\text {deviation fromavg. } z}+\underbrace{\sum_{r=2}^{t} \sum_{z=1}^{Z} \frac{1}{2}\left(\overline{\zeta_{j r}^{z}}+\overline{\zeta_{j r}^{z}-1}\right)\left(\overline{z_{j r}}-\overline{z_{j r}-1}\right)}_{\text {yearlychangein } z}]
\end{aligned}
$$

where $q_{i j t}$ is the $\log$ of output, $\zeta_{i j t}^{z}$ is the revenue share of input $z$, and $z_{i j t}$ is the $\log$ of input z. A firm's TFP is the deviation of its output from average output in that year, along with how average output in that year differs from the base year, minus the deviation of the firm's inputs from average inputs in that year, along with how average inputs in that year differ from the base year. Inputs include labor, capital, and material input; inputs and output are measured and deflated as discussed in Section 3.1. Bars over variables indicate average values within a particular industry and year. Revenue shares for labor and material inputs are calculated as the share of each input in total revenue; capital's revenue share is assumed to be one minus the sum of the other two shares.

\subsection{Decomposing All-India TFP Growth}

We begin by looking at productivity changes for the entire manufacturing industry from 1985 to 2004. To do so, we first calculate aggregate TFP in year $t, \Phi_{t}^{A G G}$, by taking the sum of each firm's productivity $\phi_{i t}$, weighted by its market share $\psi_{i t}$. Olley and Pakes (1996) show that this measure of aggregate TFP can be decomposed into two components (hereafter referred to as the OP method):

$$
\begin{aligned}
\Phi_{t}^{A G G} & \equiv \sum_{i} \psi_{i t} \phi_{i t} \\
& =\overline{\phi_{t}}+\sum_{i}\left[\psi_{i t}-\overline{\psi_{t}}\right]\left[\phi_{i t}-\overline{\phi_{t}}\right] \\
& \equiv \Phi_{t}^{U}+R_{t}
\end{aligned}
$$


where $\overline{\phi_{t}}$ and $\overline{\psi_{t}}$ are unweighted average productivity and market share, respectively. The first component, $\Phi_{t}^{U}$, is unweighted average productivity. The second component, $R_{t}$, measures the covariance between firm productivity and market share; changes in this measure represent a reallocation of market share between firms of different productivity levels. The "new new" trade theory suggests that trade liberalization should cause the reallocation component to rise, as output is reallocated from less productive to more productive firms. In addition, it is important to note that using this decomposition, the average productivity component can change not only due to changes in productivity among existing firms, but also due to firm entry or exit. Therefore, recent trade theory suggests that the average productivity component is also likely to increase as the least productive firms exit in response to competition from trade.

We first construct these measures at the all-India level. To make the results representative of the population of firms, and consistent over time, we pre-multiply each observation by the sampling weight provided in the ASI. Furthermore, to make the results more comparable with our later regression results, we consider only firms in state-industry groups that exist over the entire period. ${ }^{11}$

Figure 2 and Table 4 present results. Following Pavcnik (2002), we normalize productivity values to be zero in 1985, so changes in productivity levels can be interpreted as growth since 1985. Between 1985 and 2004, aggregate productivity grew by 19\%. This increase in productivity implies an annual increase of slightly less than $1 \%$ per year, within the range of previous studies. ${ }^{12}$

When we consider the time period as a whole, nearly all of this increase $(17.1 \%)$ can be attributed to growth in average productivity, rather than reallocation. However, Figure 2 and Table 4 suggest that there are three distinct phases between 1985 and 2004. First, from 1985 to 1990, average productivity rose by over $8 \%$, while the reallocation component actually fell by more than $6 \%$, indicating that more productive firms lost market share to less productive firms. Starting in 1991,

\footnotetext{
${ }^{11}$ We have confirmed that including all firms makes little difference to the overall results.

${ }^{12}$ There has been an extensive debate about TFP growth in the organized Indian manufacturing sector, particularly during the 1980's; Goldar (December 7, 2002) provides a summary of a number of TFP growth estimates, and discusses many of the measurement issues involved. It is important to note that our TFP estimates are based on a gross output, rather than value-added, production function; value-added TFP growth rates tend to be much higher than gross output growth rates.
} 
this trend was reversed: average productivity fell, while reallocation productivity rose sharply. By 1998, however, average productivity improvements were once again the more important driver of aggregate productivity growth. Reallocation productivity remained at approximately the level it achieved between 1992 and 1993, but rose no further.

Our results suggest that market-share reallocations did play an important role in aggregate productivity growth, but only during the few years immediately following the start of the 1991 reforms. Over the longer time horizon, average productivity improvements remained more important in explaining the increase in aggregate TFP.

\subsection{Robustness of the TFP Decomposition}

The OP decomposition has the advantage of being applicable even in the cross-sectional setting. However, it does not allows us to distinguish between productivity changes attributable to survivors, entrants, and exiters. Melitz and Polanec (2010) provide a critical appraisal of several decomposition methods that take advantage of panel data to decompose aggregate productivity growth into the contributions of each of these groups. They also suggest a new "dynamic OlleyPakes decomposition.” In this section, we show how using the Melitz and Polanec (2010) decomposition, hereafter referred to as MP, affects our results. It is important to caveat this exercise by referring back to our earlier discussion in Section 3.2 regarding the difficulty in accurately identifying firm exit in our panel. Below, we first show that under a plausible set of assumptions about firm exit, the MP decomposition yields similar results to the OP decomposition in our dataset. However, we also illustrate that under different (arguably implausible) assumptions about firm exit, the MP decomposition can lead to fundamentally different results.

To apply the MP decomposition, we first divide the population of firms in any two consecutive periods $t-1$ and $t$ into firms present in both periods (survivors), firms that exit after period $t-1$ (exiters), and firms that enter in period $t$ (entrants). In period $t-1$ only exiters and survivors are present; $S_{X, t-1}$ denotes the market share associated with exiters. In period $t$ only entrants and survivors are present; $S_{E, t}$ denotes the market share associated with entrants. MP show that the 
change in aggregate productivity from period $t-1$ to $t$ can be decomposed as follows:

$$
\Phi_{t}^{A G G}-\Phi_{t-1}^{A G G}=\left[\Phi_{S, t}^{U}-\Phi_{S, t-1}^{U}\right]+\left[R_{S, t}-R_{S, t-1}\right]+S_{E, t}\left[\Phi_{E, t}^{A G G}-\Phi_{S, t}^{A G G}\right]+S_{X, t-1+}\left[\Phi_{S, t-1}^{A G G}-\Phi_{X, t-1}^{A G G}\right]
$$

The first and second terms on the right-hand-side represent changes in within-firm productivity, and the covariance between productivity and market share, of firms that survive from $t-1$ to $t$. The third term represents the contribution of firms that enter in period $t$, weighted by the market share of entrants, $S_{E, t}$; note that their contribution will only be positive if the productivity of entrants is higher than the productivity of surviving firms in period $t$. Similarly, the last term represents the contribution of firms that exit in period $t-1$, weighted by the market share of exiters, $S_{X, t-1}$, and will only be positive if the productivity of exiters is lower than the productivity of surviving firms in period $t-1$. It is also important to note that the productivity of a firm that enters in, for example, 1990, is associated with entrants when calculating TFP growth from 1989 to 1990, but with survivors when calculating TFP growth from 1990 to 1991 . We use this method to calculate the change in TFP between period $t-1$ and period $t$, then add the change in TFP to the existing level of TFP in period $t-1$. TFP is normalized to be zero in 1985. In this analysis, we do not use the sampling multipliers.

To use this method, we have to assign every firm in our panel to the category of survivor, entrant, or exiter in every year. Given the nature of our panel data, this requires two relatively strong assumptions. First, to address the fact that we do not directly calculate TFP for 1995-1997, we impute missing values for TFP and output for each series that bridges these years using linear interpolation. We perform a similar linear interpolation of TFP and output for individual firms for which we have bridged over another year. ${ }^{13}$ Second, we have to make some assumptions regarding firm exit. When we observe a potential exiter, it is unclear whether the firm actually exited, whether it still existed but was not surveyed in the following year, or whether it was surveyed but we failed to match it. ${ }^{14}$

\footnotetext{
${ }^{13}$ For example, if a firm was surveyed in 1992 and 1994, and we are able to link that firms across those years, we use a linear interpolation to estimate TFP and output for that firm in 1993.

${ }^{14}$ In the pre-formed panel from 1998-2004, the third case is not a concern, though we are still unable to distinguish
} 
We address this challenge by first estimating the "true" rate of exit for each cohort of firms (e.g., firms born between 1974 and 1976). Figure 3 shows the pattern of survival observed for each cohort. In each year, we then consider the potential pool of exiting firms (i.e., firms we do not observe in any subsequent year), and use one of several algorithms to assign exit to the number of the firms we estimate to have exited from each cohort. The remaining firms are assigned to the group of survivors.

There are a number of ways to select firms for exit from the potential pool of exiters. To choose an appropriate strategy, we examined the distribution of TFP for potential exiters versus survivors, for two years (1999-2000) in which observed exit rates are relatively close to estimated exit rates, indicating that the pool of potential exiters is likely to be representative of "true" exiters (Figure 4, Panels (a) and (c)). We also examined TFP distributions in two years (1995 and 2004) when the observed exit rate is significantly higher than the estimated, true exit rate, indicating that many true survivors are classified as exiters (Figure 4, Panels (b) and (d)). In both cases, the distributions of potential exiters are slightly left-shifted, indicating that exiters are, on average, less productive than survivors. However, the two distributions of potential exiters are similarly left-shifted relative to the distributions of survivors, suggesting that one way to assign exit in years with significant amounts of false exit, is to select a random sample of firms from the pool of potential exiters.

Figure 5 shows the results of the MP decomposition model when exit is assigned in this manner. ${ }^{15}$ The MP decomposition tells a similar story as the OP decomposition. Aggregate productivity growth was driven largely by increases in average productivity growth among survivors. However, reallocation among survivors was somewhat more important during the years immediately following the start of the 1991 reforms, and between 1995 and 1998 (this finding was not observed in the population data as we were unable to interpolate TFP during those years). Entrants and exiters played a relatively small role in explaining overall productivity changes; however, it is important to note that the decomposition only considers the contributions of entrants and exiters between the first two cases in many instances.

${ }^{15} \mathrm{By}$ construction, aggregate TFP is the same for the MP and OP methods; however, there are some slight differences between aggregate TFP in Figure 5 and in Figure 2, due to the subset of firms used in the panel versus the population. 
in the year of entry or exit (e.g., in the second year in which we observe a firm, it is considered a survivor). The small negative contribution of entrants may simply reflect the relatively low productivity of young firms (see Section 4.5).

Figure 5 is based on the assignment of exit that we feel to be most appropriate. However, given the uncertainty surrounding exit, we also show the results under three different scenarios: (1) without correcting for false exit, (2) assuming that the least productive firms from the pool of potential exiters are the true exiters, and (3) assuming that the most productive firms from the pool of potential exiters are the true exiters. Figure 6 shows the results from conducting the MP decomposition with these alternative assumptions. If we do not correct for false exit, we find a nearly $40 \%$ increase in the reallocation component of TFP, and a $10 \%$ decrease in average TFP among survivors. If we assume that all of the least productive firms exit, the decomposition implies a $70 \%$ growth in reallocation productivity, and a $50 \%$ fall in average productivity. The opposite happens if we assume that the most productive firms exit: average productivity rises by over $60 \%$, while reallocation productivity falls by nearly $20 \%$. As we would expect, firm exit increases (decreases) aggregate productivity when we assume that the least (most) productive firms exit.

As discussed above, we feel that these assumptions are implausible given the distribution of TFP observed for exiting firms in the years where we are confident about correctly identifying exit. However, it is clear that the MP decomposition is sensitive to correctly identifying firm exit. We therefore use the OP decomposition as our main specification for the remainder of the paper. Nonetheless, in Section 4.4 we also show that under our preferred assumptions regarding exit, the MP and OP decompositions imply a similar relationship between the policy reforms and industry-level productivity changes. In a broader context, our findings suggest that researchers using panel datasets in which entry and exit may be uncertain, should use caution when applying decomposition methods that rely on accurately identifying entry and exit. 


\subsection{Industry-Level TFP Changes and Policy Reforms}

To what extent can the increase in productivity be attributed to the trade and other policy reforms that occurred during the 1990's? To answer this question, we exploit the variation in those policies across industries to examine whether changes in the individual components of productivity were systematically related to specific reforms.

In order to use the policy variation across industries, we re-create our aggregate, average, and reallocation TFP measures at the state-industry level. We use the state-industry level because this level of disaggregation allows us to consider variations in policies and other characteristics across both industries and states, and because the ASI survey is designed to be representative at this level. Figure 7 and Table 5 present the average results across all groups, weighting each group by the total number of firms that appear in that group across all years. Doing so ensures that the results are more comparable to the all-India results, since larger state-industry groups are given more weight.

This weighting scheme ensures that average productivity is nearly the same at the state-industry and all-India levels. However, the reallocation component is lower across most years at the stateindustry level. The reason is that at this level, we can only measure reallocation within stateindustry groups. For example, suppose that the steel industry is more productive than the chemical industry, and that all firms in the steel industry increase output by $10 \%$, while all firms in the chemical industry reduce output by $10 \%$. The all-India reallocation measure will increase, but the state-industry reallocation measure will not. While it would be ideal to capture between-industry as well as within-industry market-share reallocations, our identification strategy (described below) does not allow us to use an all-India measure of productivity. Nonetheless, despite some differences, the reallocation component at the state-industry level follows the same basic pattern as the all-India measure.

We exploit the fact that the trade, licensing, and FDI reforms occurred differentially across industries to isolate the impacts of each policy on each productivity measure. Consider the relationship between our outcomes of interest and the reforms: 


$$
\widehat{Y_{j s t}}=\beta_{1} \tau_{j, t-1}+\beta_{2} \tau_{j, t-1}^{I}+\beta_{3} \text { Delic }_{j, t-1}+\beta_{4} F D I_{j, t-1}+\alpha_{j s}+\alpha_{t}+\varepsilon_{j s t}
$$

where $\widehat{Y_{j s t}}$ is estimated aggregate $\operatorname{TFP}\left(\widehat{\Phi_{j s t}^{A G G}}\right)$, average $\operatorname{TFP}\left(\widehat{\Phi_{j s t}^{U}}\right)$, or reallocation $\left(\widehat{R_{j s t}}\right)$ for industry $j$ and state $s$ at time $t, \tau_{j, t-1}$ and $\tau_{j, t-1}^{I}$ are final goods tariffs and input tariffs, Delic $c_{j, t-1}$ is a dummy variable equal to one if any products in an industry are delicensed, zero otherwise, $F D I_{j, t-1}$ is a dummy variable equal to one if any products in an industry are FDI-liberalized, zero otherwise; and $\alpha_{j s}$ and $\alpha_{t}$ are state-industry and year dummy variables, respectively. Since our firm data are annual, and policy changes occurred throughout the year, we lag all policy variables by one year. We employ a fixed-effects estimator to estimate Equation 2, and cluster all standard errors at the state-industry level. We use the balanced panel of state-industries in order to avoid confounding within-group effects with the entry and exit of certain industries in particular states, and we weight all observations using the total number of firms in each state-industry group over all years. This ensures that industries (and states) with large firm populations will receive higher weight in the analysis, and will make the results more representative of the all-India level. ${ }^{16}$

Table 6 presents baseline results for 1986 to $2004 .{ }^{17}$ Column (1) suggests that the trade liberalization is strongly correlated with aggregate productivity increases. The coefficient on final goods tariffs $(-0.055)$ indicates that a 10 percentage point reduction in final goods tariffs yields an $0.55 \%$ increase in aggregate productivity. The impact of input tariffs is an order of magnitude larger, with a 10 percentage point reduction in input tariffs yielding a 5.6\% increase in aggregate productivity. Moreover, FDI liberalization increases aggregate productivity by $2.3 \%$.

Columns (2) and (3) present results for the average and reallocation components of productivity, respectively. Column (2) indicates that 10 percentage point declines in final goods and input tariffs raise average productivity by $0.44 \%$ and $5.6 \%$, respectively, though the coefficient on final goods tariffs is not statistically significant at the $10 \%$ level. FDI liberalization increases average

\footnotetext{
${ }^{16}$ The results are robust to not including these weights; see Appendix A.

${ }^{17}$ We exclude 1985 because we do not have lagged policy variables for this year.
} 
productivity by $4.9 \%$. However, Column (3) shows that the variation in individual polices cannot explain the increase in reallocation. The only statistically significant result, for FDI reform, indicates that liberalization would lower rather than raise reallocation productivity.

Table 7 shows the results of performing a similar exercise using the MP decomposition, with our preferred assignment of exit. In this case, the number of state-industry observations is larger due to the imputation of TFP in the panel, as discussed in Section 3.2. Using this decomposition, a 10 percentage point decline in input tariffs is associated with a $4.2 \%$ increase in aggregate productivity, and a 5\% increase in average productivity. FDI liberalization also increases aggregate productivity by $4.1 \%$, and average productivity by $4.3 \%$. The policy reforms are not associated with the other components of productivity growth (reallocation among survivors or entry/exit).

In Appendix A, we also test the robustness of the baseline, OP results to a number of different ways of measuring productivity and capital, weighting state-industry level observations, and other factors. The results are all broadly similar, and suggest that the trade and FDI reforms are both associated with increased productivity.

In Table 8, we use the baseline results to show the extent to which the policy reforms can explain overall productivity growth. In particular, we multiply the coefficients from the results in Table 6 by the average policy change, to estimate the productivity growth implied by each reform. The results suggest that trade liberalization, in particular the decline in input tariffs, is largely responsible for aggregate and average productivity growth. The decline of 60 percentage points in final goods tariffs implies an aggregate productivity increase of 3.2\%, and an average productivity increase of $2.6 \%$ (though the related regression coefficient is not statistically significant). Meanwhile, the decline of 40 percentage points in input tariffs implies aggregate and average productivity increases of nearly $22 \%$. The FDI liberalization also plays a role, implying a $4.6 \%$ increase in average productivity. ${ }^{18}$ As discussed above, the variation in policies across industries cannot explain the gains in reallocation productivity that were observed in the initial years following the

\footnotetext{
${ }^{18}$ In fact, the average policy changes can explain somewhat more than the total increase in productivity during this time period. In the regression framework, the coefficients on several year dummies are negative, implying that in the absence of the policy reforms, productivity would have fallen.
} 
reforms. However, the policies do explain the gains in average productivity, which was the more important driver of aggregate productivity growth during this period.

\subsection{Firm-Level Regressions}

We now use the constructed panel to examine the results on average productivity in more detail. As discussed above, the average productivity measure we use can increase either because existing firms increase their productivity, or because less productive firms exit, or more productive firms enter.

The panel allows us to explore this issue by isolating within-firm productivity improvements. We estimate the following equation at the firm level:

$$
\widehat{\phi_{i j s t}}=\beta_{1} \tau_{j, t-1}+\beta_{2} \tau_{j, t-1}^{I}+\beta_{3} \text { Delic }_{j, t-1}+\beta_{4} F D I_{j, t-1}+\alpha_{i}+\alpha_{t}+\varepsilon_{i j s t}
$$

We use a fixed-effects estimator, which allows us to identify within-firm changes in productivity.

Table 9 presents results. In Column (1), we include all firms that were used in the state-industry level analysis (the estimated population). This specification includes industry and year dummy variables. As we would expect, the coefficients on the policy variables are similar to the average productivity results at the state-industry level.

Column (2) presents results for firms that appear in the panel for at least two years, without sampling multipliers. This specification includes industry and year dummy variables, but not firm fixed effects, and indicates that the results for the sample of firms that are in the panel are similar to the overall results. Column (3) controls for a number of firm characteristics, and shows that public firms and young firms (less than 3 years old) are relatively unproductive. We also created dummy variables for firms in three size categories: <20 employees (small), 20-99 employees (medium), and 100+ employees (large, the omitted category). The results indicate a positive correlation between size and productivity.

In Column (4), we present results with firm fixed effects, thus isolating within-firm changes in 
productivity. The coefficient on final goods tariffs is slightly larger (-0.042 instead of -0.036$)$ in this specification than in the specification without firm fixed effects. In contrast, the coefficient on input tariffs is smaller (-0.13 rather than -0.54$)$, as is the coefficient on FDI reform (0.031 instead of 0.053 ), though both coefficients remain statistically significant at the $1 \%$ level.

These results confirm that the trade and FDI liberalizations are associated with substantial increases in productivity within individual firms. However, they also indicate that the changing composition of firms, as well as unobserved, firm-level characteristics, may play important roles in the observed, average productivity gains for the population of firms. ${ }^{19}$

\subsection{State and Industry Characteristics}

We now explore the extent to which the effects of the reforms varied across states or industries with different pre-reform characteristics. First, we consider the role of labor regulations. Although India reformed a number of its industrial policies in the 1990's, labor regulations remained stringent. Besley and Burgess (2004) show that Indian states with stricter labor regulations had lower output than other states. Building on their work, Aghion et al. (2008) demonstrate that the effects of delicensing on output growth were lower in states with stricter labor regulations. We explore the extent to which state-level labor regulations may have affected each component of productivity growth. One important aspect of the labor regulations is that large firms must obtain government permission to shut down or to lay off workers; this requirement may have affected productivity by making it difficult to achieve the optimal input mix or to shut down.

We use two measures of labor regulations. First, we use the measure developed by Besley and Burgess (2004), who classify state amendments to India's Industrial Disputes Act (IDA) as "proworker" or "pro-employer". This measure of labor regulations exhibits very few changes during the time period we consider, and only one state moves from one category to another. Therefore, we classify states as neutral, pro-worker, or pro-employer based on their cumulative score in 1985,

\footnotetext{
${ }^{19}$ Similarly, Topalova and Khandelwal (forthcoming), who study productivity among 4,100 large Indian firms, find that the effects of final goods and input tariffs are somewhat attenuated when including firm fixed effects.
} 
and interact all policy variables in Equation 2 with an indicator for whether the state was proworker or pro-employer in 1985. The inclusion of state-industry fixed effects controls for timeinvariant, state-level characteristics. In addition to this de jure measure of labor regulations, we have developed a de facto measure of how easy it is for firms to adjust their size or shut down based on court outcomes. We gathered data from various publications of the Ministry of Labor that provided the number of times a firm requested permission to close down or to lay off workers between 1988 and 1992, as well as the number of cases in which permission was granted or denied. We calculated the fraction of cases in which permission was granted, and constructed a dummy variable equal to one for states in which the fraction granted was above the median.

Tables 10 and 11 present results for the two measures of labor regulations. ${ }^{20}$ The effects of all policy reforms, except FDI liberalization, are largely similar across states, regardless of labor regulations. Table 11 indicates that FDI reform is associated with a 7\% increase in average productivity in states where it is difficult to lay off workers, but only a $2.5 \%(7 \%-4.5 \%)$ increase in average productivity in states where it is easy to lay off workers. This difference suggests that in states where it is difficult for firms to achieve an optimal input mix by laying off workers, they may instead be able to increase their productivity through other means, such as attracting FDI. In other words, FDI reform matters more when existing rigidities make it difficult for firms to optimize their production.

Another factor that may have influenced the impact of liberalization on firm productivity is exposure to trade. We use three measures as proxies for trade exposure. First, firms located close to ports may have been more exposed to trade competition prior to the reforms, or may have been more affected by trade liberalization. We create a dummy variable that is equal to one if a stateindustry group is located in a state with a port, zero otherwise. We also develop measures of the extent to which particular industries might have been more or less exposed to competition from imports, or to foreign markets through exports. To so do, we use data from the COMTRADE database to estimate total exports and total imports for each industry in 1990. We then calculate

\footnotetext{
${ }^{20}$ The samples we use are restricted to states for which we have data on labor regulations, and are therefore smaller than the baseline sample.
} 
the shares of imports and exports in output for each industry. Our importing (exporting) variable is a dummy equal to one if the industry has an import (export) share in output that is above the median, zero otherwise.

The advantage of using the 1990 measure is that it captures pre-reform industry characteristics. However, this means that we lose variation across time, so we interact our measures of trade exposure with the reforms. In addition, if certain industries became relatively more exposed to trade as a result of the reforms, and were thus further impacted by trade, we will not capture this effect.

Table 12 shows the results of interacting each of these measures with our policy change variables. The most notable finding is that the delicensing and FDI reforms have larger effects on productivity in industries and states that were relatively less exposed to trade. In states without ports, and in non-importing industries, delicensing is associated with a 4-5\% increase in average productivity. Meanwhile, FDI reform is associated with a $7.5 \%$ increase in average productivity among non-exporting industries. The effect of the FDI reform on average productivity is attenuated in exporting industries, while the effect of the delicensing reforms is actually reversed in non-importing industries and in states with ports. These results suggest some degree of substitutability between external competition and internal competition: where states or industries were not already exposed to trade through proximity to ports, import competition, or exposure to foreign markets, industrial reforms that encouraged competition had a larger effect.

\subsection{Firm Size}

In this section, we explore the extent to which the productivity changes may have differed across firms of different sizes. Using the population data, but harnessing information from the panel, we classify firms into three categories: small (<20 employees), medium (20-99 employees), and large $\left(100+\right.$ employees) based on the size the firm was the first time we observed it. $^{21}$

\footnotetext{
${ }^{21}$ The results are similar when we classify firms based on their current size, thus allowing firms to switch between categories.
} 
Figure 8 indicates that for firms in the small and medium size classes, changes in average productivity are more important than reallocation in driving aggregate productivity growth, over the 20-year period from 1985 to 2004 . Interestingly, reallocation and average productivity are both equally important for large firms. All three size classes show an increase in reallocation productivity immediately following 1991; however, while this term rises in later years for large firms, it remains stagnant for small and medium-sized firms. In contrast, large firms also show a decline in average productivity just before the 1991 reforms, as well as during the early 2000's.

Table 8 shows the regression results, by firm size. Note that the number of state-industries in the balanced panel varies by size, as all state-industry samples do not contain firms in each size class in every year. The results indicate that the decline in input tariffs is associated with an increase in aggregate and average productivity across all size classes. The decline in final goods tariffs is not related to average productivity in a statistically significant way, but does increase aggregate productivity among small and medium-sized firms, as well as reallocation productivity among small firms. ${ }^{22}$ FDI liberalization is most important for large firms: reform is associated with a $7.9 \%(9.1 \%)$ increase in aggregate (average) productivity for firms with 100 or more employees, approximately twice the magnitude of the average effect. Finally, the delicensing reforms, while not associated with overall productivity increases, are associated with a $4.5 \%$ increase in aggregate productivity, and a $3.1 \%$ increase in reallocation productivity, among large firms. This heterogeneity by size class is consistent with the fact that only firms with 50 or more employees, and a certain amount of assets, were required to obtain operating licenses under the license raj.

\section{Conclusion}

Our results confirm that the market-share reallocations predicted by recent trade theory were important in increasing India's productivity growth during the years immediately following the start of the major trade reforms. We document three distinct periods during the years from 1985 to

\footnotetext{
${ }^{22}$ The magnitude of the effect of input tariffs on reallocation productivity among small firms may actually be larger, but is not statistically significant.
} 
2004. First, from 1985 to 1990, increases in aggregate (output-weighted) productivity were nearly exclusively due to increases in average (unweighted) productivity, while reallocation productivity actually fell. Between 1991 and 1994, reallocation productivity rose sharply while average productivity initially fell, then rose more slowly. Finally, from 1998 onwards, reallocation productivity stagnated, while average productivity improvements once again became more important.

The increases in aggregate productivity are linked to the trade and FDI liberalization that took place during the 1990's. Our main specification indicates that the average declines in final goods and input tariffs were associated with aggregate productivity increases of $3.2 \%$ and $21.8 \%$, respectively. Meanwhile, the FDI reforms implied an aggregate productivity increase of $2.1 \%$. Using a constructed panel of firms from from 1985 to 2004, we confirm that the trade and FDI reforms were associated with increases in within-firm productivity, after controlling for unobservable, timeinvariant firm characteristics. We also use the panel to illustrate the importance of correctly identifying firm exit when using decomposition methods that rely on the panel nature of the data.

Our results lend support to the importance of market-share reallocations in increasing productivity. In the case of India, however, we show that such reallocations were only important at the beginning of the major trade liberalization period, and that over the 20-year period from 1985 to 2004, average productivity improvements played a larger role in determining aggregate productivity growth.

\section{References}

Aghion, Philippe, Robin Burgess, Stephen Redding, and Fabrizio Zilibotti, “The Unequal Effects of Liberalization: Evidence from Dismantling the License Raj in India," The American

Economic Review, September 2008, 98 (4), 1397-1412.

Amiti, Mary and Jozef Konings, “Trade Liberalization, Intermediate Inputs, and Productivity:

Evidence from Indonesia,” The American Economic Review, December 2007, 97 (5),

$1611-1638$. 
Arkolakis, Costas, "Market Penetration Costs and the New Consumers Margin in International Trade,” Journal of Political Economy, 2010, 118 (6), 1151-1199.

Aw, Bee Yan, Xiaomin Chen, and Mark J. Roberts, "Firm-level evidence on productivity differentials and turnover in Taiwanese manufacturing," Journal of Development Economics, 2001, 66 (1), 51-86.

Bernard, A. B., J. B. Jensen, and Peter K. Schott, “Trade Costs, Firms and Productivity,” Journal of Monetary Economics, 2006, 53, 917-937.

_ J. Eaton, J. B. Jensen, and S. S. Kortum, "Plants and Productivity in International Trade," The American Economic Review, 2003, 93 (4), 1268-1290.

Berthou, Antoine and Lionel Fontagne, "How do Multi-Product Exporters React to a Change in Trade Costs?," April 2010. Working Paper.

Besley, Timothy and Robin Burgess, "Can Labor Regulation Hinder Economic Performance? Evidence from India," Quarterly Journal of Economics, February 2004, 119 (1), 91-134.

Corden, W. Max, Trade Policy and Economic Welfare, Oxford: Clarendon Press, 1974.

Debroy, B. and A.T. Santhanam, "Matching Trade Codes with Industrial Codes," Foreign Trade Bulletin, July 1993, 24 (1), 5-27.

Eaton, Jonathan, Samuel Kortum, and Francis Kramarz, "An Anatomy of International Trade: Evidence from French Firms,” December 2008. NBER Working Paper 14610.

Fernandes, Ana M., "Trade policy, trade volumes and plant-level productivity in Colombian manufacturing industries,” Journal of International Economics, 2007, 71 (1), 52-71.

Goldar, Bishwanath, “TFP Growth in Indian Manufacturing in 1980s,” Economic and Political Weekly, December 7, 2002, pp. 4966-4968.

Grossman, Gene and Elhanan Helpman, Innovation and Growth in the Global Economy, Cambridge: MIT Press, 1991.

Harrison, Ann, "Productivity, imperfect competition and trade reform: Theory and evidence," Journal of International Economics, 1994, 36, 53-73.

Hasan, Rana, Devashish Mitra, and K. V. Ramaswamy, “Trade Reforms, Labor Regulations, and 
Labor Demand Elasticities: Empirical Evidence from India," The Review of Economics and Statistics, August 2007, 89 (3), 466-481.

Helpman, Elhanan and Paul R. Krugman, Market Structure and Foreign Trade: Increasing Returns, Imperfect Competition, and the International Economy, Cambridge: The MIT Press, 1985.

, Marc J. Melitz, and Stephen R. Yeaple, "Export Versus FDI with Heterogeneous Firms,” The American Economic Review, March 2004, 94 (1), 300-316.

Manova, Kalina and Zhiwei Zhang, "Export Prices across Firms and Destinations," November 2010. Working Paper.

Melitz, Marc J., “The Impact of Trade on Intra-Industry Reallocations and Aggregate Industry Productivity," Econometrica, November 2003, 71 (6), 1695-1725. and Saso Polanec, "Dynamic Olley-Pakes Decomposition with Entry and Exit," December 2010. INNODRIVE Working Paper No. 11.

Menezes-Filho, Naercio Aquino and Marc-Andreas Muendler, "Labor Reallocation in Response to Trade Reform," November 2007. Working Paper.

Nataraj, Shanthi, “The Impact of Trade Liberalization on Productivity and Firm Size: Evidence from India's Formal and Informal Manufacturing Sectors," September 2010. Working Paper. Olley, G. Steven and Ariel Pakes, "The Dynamics of Producticity in the Telecommunications Equipment Industry," Econometrica, 1996, 64 (6), 1263-1297.

Pavcnik, Nina, "Trade Liberalization, Exit, and Productivity Improvements: Evidence from Chilean Plants," Review of Economic Studies, 2002, 69 (1), 245-276.

Sivadasan, Jagadeesh, "Barriers to Competition and Productivity: Evidence from India,” The B.E. Journal of Economic Analysis \& Policy, 2009, 9 (1 (Advances)), Article 42.

Topalova, Petia and Amit Khandelwal, "Trade Liberalization and Firm Productivity: The Case of India," The Review of Economics and Statistics, forthcoming.

Trefler, Daniel, "The Long and Short of the Canada-U.S. Free Trade Agreement," The American Economic Review, September 2004, 94 (4), 870-895. 
Tybout, James and M. Daniel Westbrook, "Trade liberalization and the dimensions of efficiency change in Mexican manufacturing industries," Journal of International Economics, 1995, 39, $53-78$. 
Figure 1: Trade Reforms

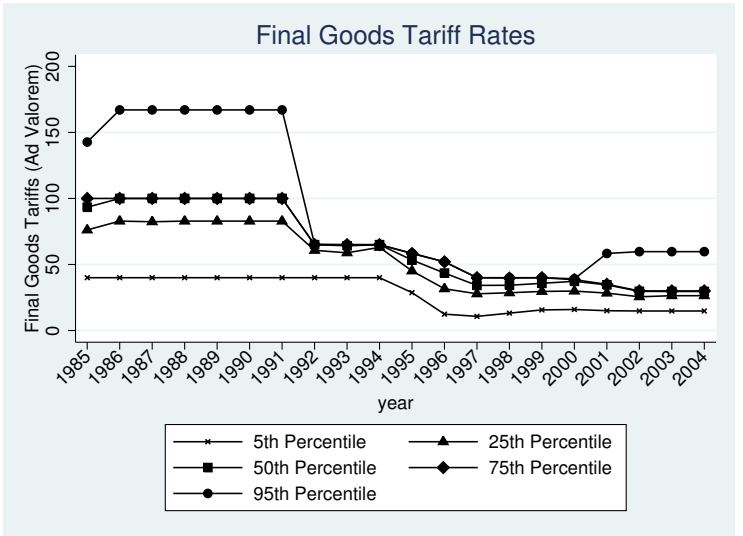

(a) Final Goods Tariffs

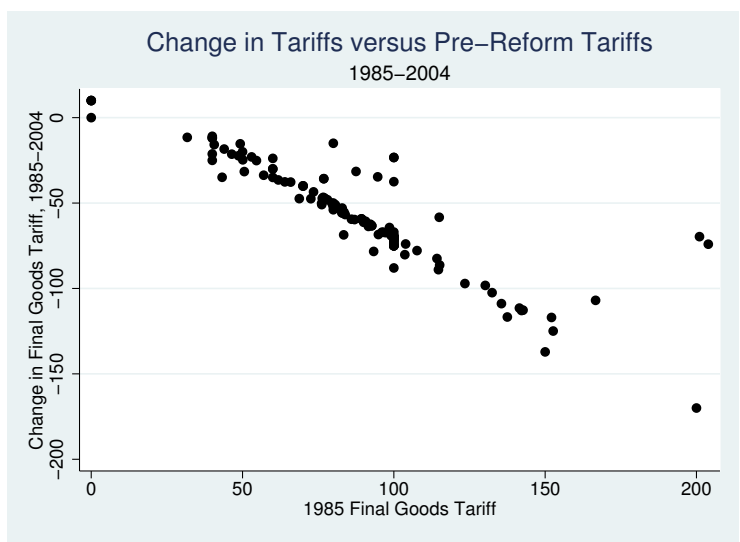

(c) Change in Tariffs vs. Pre-Reform Tariffs, 19852004

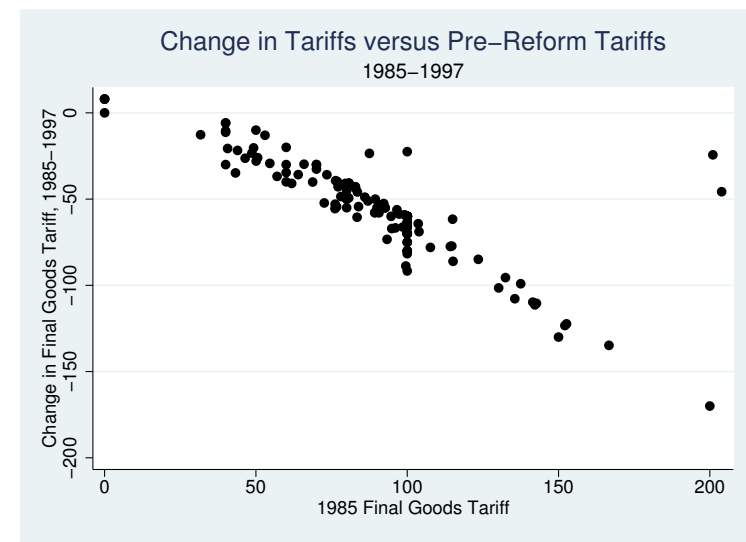

(b) Change in Tariffs vs. Pre-Reform Tariffs, 19851997

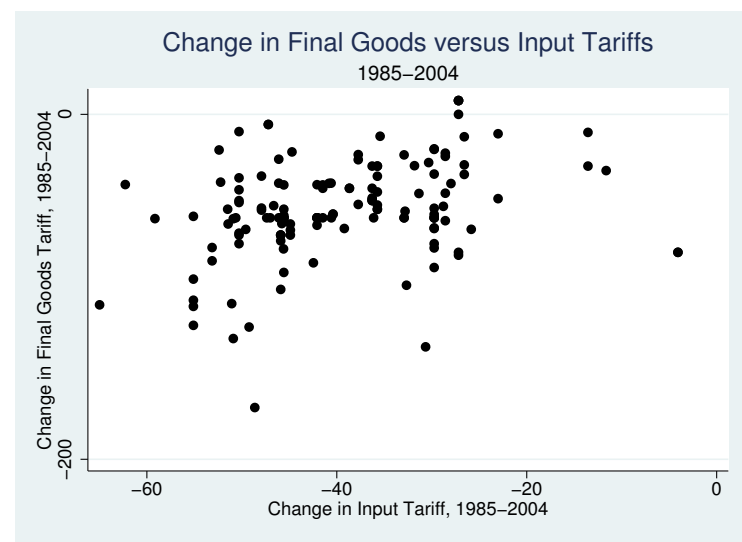

(d) Changes in Final Goods versus Input Tariffs, 19852004

Panel (a) shows the 5th, 25th, 50th, 75th, and 95th percentiles of final goods tariffs by 3-digit National Industrial Classification (NIC) code in each year. Panels (b) and (c) show the relationship between 1985 final goods tariffs and the changes in final goods tariffs through 1997 and 2004, respectively. Panel (d) shows the relationship between the changes in final goods and input tariffs between 1985 and 2004. Source: Authors' calculations based on TRAINS and various publications of the Government of India. 
Table 1: Trade, FDI, and Licensing Reforms

\begin{tabular}{ccccc} 
Year & Final Goods Tariffs & Input Tariffs & FDI Reform & Delicensing \\
\hline 1985 & 0.89 & 0.58 & 0.00 & 0.34 \\
1986 & 0.96 & 0.61 & 0.00 & 0.35 \\
1987 & 0.95 & 0.59 & 0.00 & 0.35 \\
1988 & 0.95 & 0.60 & 0.00 & 0.35 \\
1989 & 0.96 & 0.60 & 0.00 & 0.36 \\
1990 & 0.96 & 0.60 & 0.00 & 0.36 \\
1991 & 0.96 & 0.60 & 0.36 & 0.84 \\
1992 & 0.64 & 0.40 & 0.36 & 0.84 \\
1993 & 0.64 & 0.39 & 0.36 & 0.85 \\
1994 & 0.64 & 0.37 & 0.36 & 0.85 \\
1995 & 0.53 & 0.30 & 0.36 & 0.85 \\
1996 & 0.42 & 0.23 & 0.36 & 0.85 \\
1997 & 0.34 & 0.18 & 0.43 & 0.89 \\
1998 & 0.35 & 0.19 & 0.43 & 0.93 \\
1999 & 0.36 & 0.20 & 0.43 & 0.93 \\
2000 & 0.35 & 0.21 & 0.93 & 0.93 \\
2001 & 0.34 & 0.21 & 0.93 & 0.93 \\
2002 & 0.31 & 0.19 & 0.93 & 0.93 \\
2003 & 0.31 & 0.19 & 0.93 & 0.93 \\
2004 & 0.31 & 0.19 & 0.93 & 0.93 \\
\hline \hline
\end{tabular}

Mean values of policy variables from 1985 to 2004. Final goods and input tariffs variables are fractions, with 1 representing an ad valorem tariff of 100\%; FDI Reform is a dummy variable equal to 1 if any products within the industry are liberalized, 0 if not; and Delicensing is a dummy variable equal to 1 if any products within the industry are delicensed, 0 if not. Source: Authors' calculations based on various publications of the Government of India, as well as the TRAINS database. 
Table 2: Changes in Reforms and Pre-Reform Trends in Industry Characteristics

\begin{tabular}{lcccc} 
& $\Delta$ Final Goods Tariffs & $\Delta$ Input Tariffs & $\Delta$ FDI Reform & $\Delta$ Delicensing \\
\hline$\Delta \log ($ wage $)$ & 0.002 & -0.042 & 0.088 & -0.14 \\
& $(0.19)$ & $(0.052)$ & $(0.12)$ & $(0.26)$ \\
$\Delta$ Production Share & -0.052 & -0.16 & 0.17 & 0.82 \\
& $(0.92)$ & $(0.25)$ & $(0.60)$ & $(1.27)$ \\
$\Delta \log ($ K/L Ratio $)$ & -0.12 & 0.007 & 0.041 & 0.043 \\
& $(0.080)$ & $(0.022)$ & $(0.052)$ & $(0.11)$ \\
$\Delta \log ($ Employment $)$ & -0.062 & -0.024 & -0.0085 & -0.034 \\
& $(0.061)$ & $(0.016)$ & $(0.04)$ & $(0.084)$ \\
$\Delta \log$ (Firm Size) & -0.096 & -0.035 & 0.018 & -0.026 \\
& $(0.12)$ & $(0.032)$ & $(0.077)$ & $(0.16)$ \\
$\Delta \log$ (Output) & -0.037 & -0.0088 & 0.02 & -0.0028 \\
& $(0.040)$ & $(0.011)$ & $(0.026)$ & $(0.055)$ \\
$\Delta$ TFP (Total) & 0.038 & -0.0066 & 0.062 & 0.014 \\
& $(0.072)$ & $(0.020)$ & $(0.047)$ & $(0.099)$ \\
\hline Observations & 136 & 136 & 136 & 136 \\
\hline \hline
\end{tabular}

Results are coefficients from regressions of the change in reforms (final goods tariffs, input tariffs, delicensing, FDI reform) from 1990 to 2004 on changes in industry characteristics from 1985 to 1989. Each value represents a result from a separate regression. Standard errors are in parentheses. 
Table 3: Summary Statistics for the Firm-Level Data

\begin{tabular}{lrrr} 
& $\begin{array}{r}\text { Estimated } \\
\text { population }\end{array}$ & $\begin{array}{r}\text { Sampled } \\
\text { firms }\end{array}$ & Panel \\
\hline Firm-years & $1,410,341$ & 580,122 & 413,758 \\
Firms per year, mean & 82,961 & 34,124 & 24,338 \\
Census firm-years & 276,278 & 276,278 & 246,881 \\
Census firms per year, mean & 16,251 & 16,251 & 14,522 \\
Unique firm series & & & 147,838 \\
& & & \\
Output, mean (million Rs.) & 17.9 & 30.2 & 39.2 \\
Output, median (million Rs.) & 2.6 & 3.6 & 5.3 \\
Capital, mean (million Rs.) & 6.0 & 10.9 & 14.4 \\
Capital, median (million Rs.) & 0.4 & 0.5 & 0.8 \\
Materials, mean (million Rs.) & 12.0 & 19.9 & 25.7 \\
Materials, median (million Rs.) & 1.9 & 2.6 & 3.9 \\
Labor, mean (no. employees) & 73 & 131 & 168 \\
Labor, median (no. employees) & 21 & 31 & 43 \\
& & & \\
In panel, as fraction of total in sampled population: & \\
Output & & & 0.93 \\
Capital & & & 0.94 \\
Labor & & & 0.92 \\
Firm-years > 100 employees & & & 0.94 \\
Firm-years > 200 employees & & & 0.96 \\
Firm-years & & & 0.71 \\
Census firm-years & & & 0.89 \\
\hline \hline
\end{tabular}

Summary statistics for the estimated population (using sampling weights), for the sampled population (not using sampling weights), and for firms that appear for two or more years in the panel. Only open firms with positive values of key variables are included. "Firm-years" indicates the total number of observations, while "Census firm-years" indicates the number of observations in the census sector. Mean and median values are averages across all years used in the analysis (1985-1994 and 1998-2004). Output, material inputs and capital have been deflated to 1985 values and are expressed in millions of rupees. Fractions of output, capital, etc. that appear in the panel are given in relation to the sampled (rather than the estimated) population. Source: Authors' calculations based on Annual Survey of Industries data. 
Figure 2: All-India Total Factor Productivity

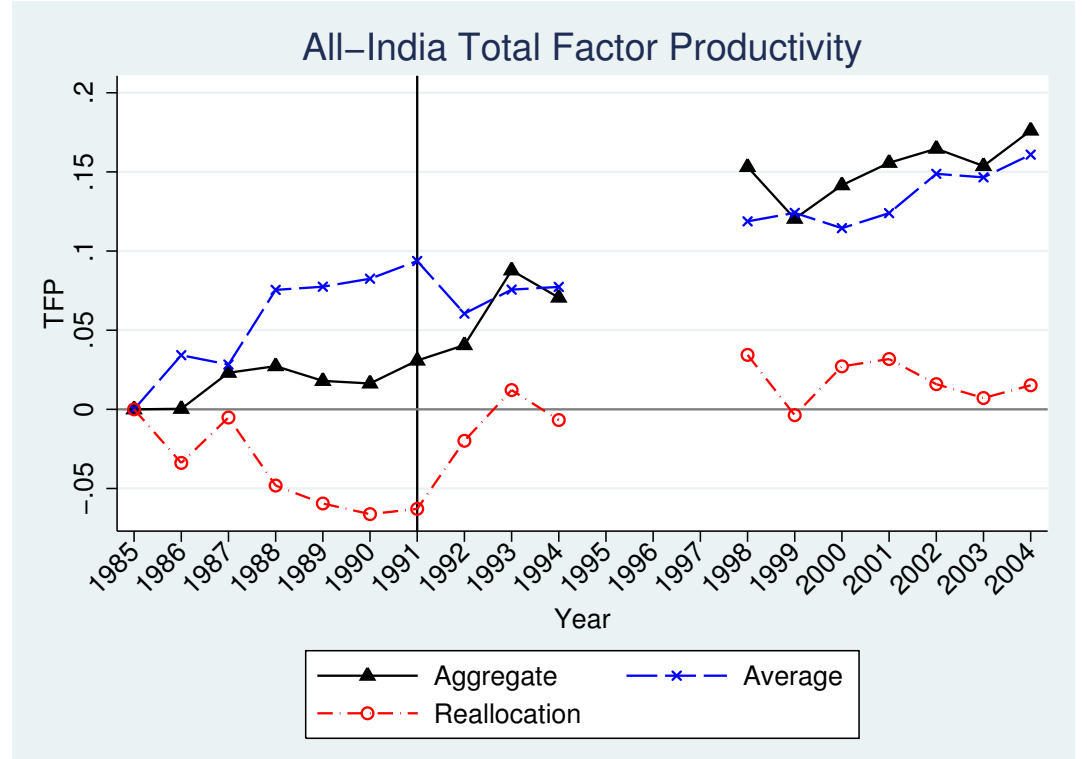

Total factor productivity (TFP) decompositions for the population of firms, conducted at the allIndia level, using the OP method. "Aggregate" indicates market-share weighted mean productivity, "Average" indicates unweighted mean productivity, and "Reallocation" indicates the covariance between market share and productivity. Source: Authors' calculations based on Annual Survey of Industries data. 
Table 4: All-India Total Factor Productivity

\begin{tabular}{rrrr} 
Year & Aggregate & Average & Reallocation \\
\hline 1985 & 0.000 & 0.000 & 0.000 \\
1986 & 0.001 & 0.026 & -0.025 \\
1987 & 0.023 & 0.027 & -0.004 \\
1988 & 0.030 & 0.074 & -0.044 \\
1989 & 0.017 & 0.075 & -0.058 \\
1990 & 0.014 & 0.081 & -0.066 \\
1991 & 0.033 & 0.094 & -0.061 \\
1992 & 0.042 & 0.057 & -0.015 \\
1993 & 0.086 & 0.070 & 0.016 \\
1994 & 0.061 & 0.074 & -0.013 \\
1998 & 0.160 & 0.124 & 0.036 \\
1999 & 0.137 & 0.131 & 0.007 \\
2000 & 0.161 & 0.127 & 0.033 \\
2001 & 0.176 & 0.137 & 0.039 \\
2002 & 0.176 & 0.158 & 0.018 \\
2003 & 0.167 & 0.155 & 0.012 \\
2004 & 0.190 & 0.171 & 0.019 \\
\hline \hline
\end{tabular}

Total factor productivity (TFP) decompositions for the population of firms, conducted at the allIndia level, using the OP method. "Aggregate" indicates market-share weighted mean productivity, "Average" indicates unweighted mean productivity, and "Reallocation" indicates the covariance between market share and productivity. Source: Authors' calculations based on Annual Survey of Industries data. 
Figure 3: Estimated Firm Survival by Cohort

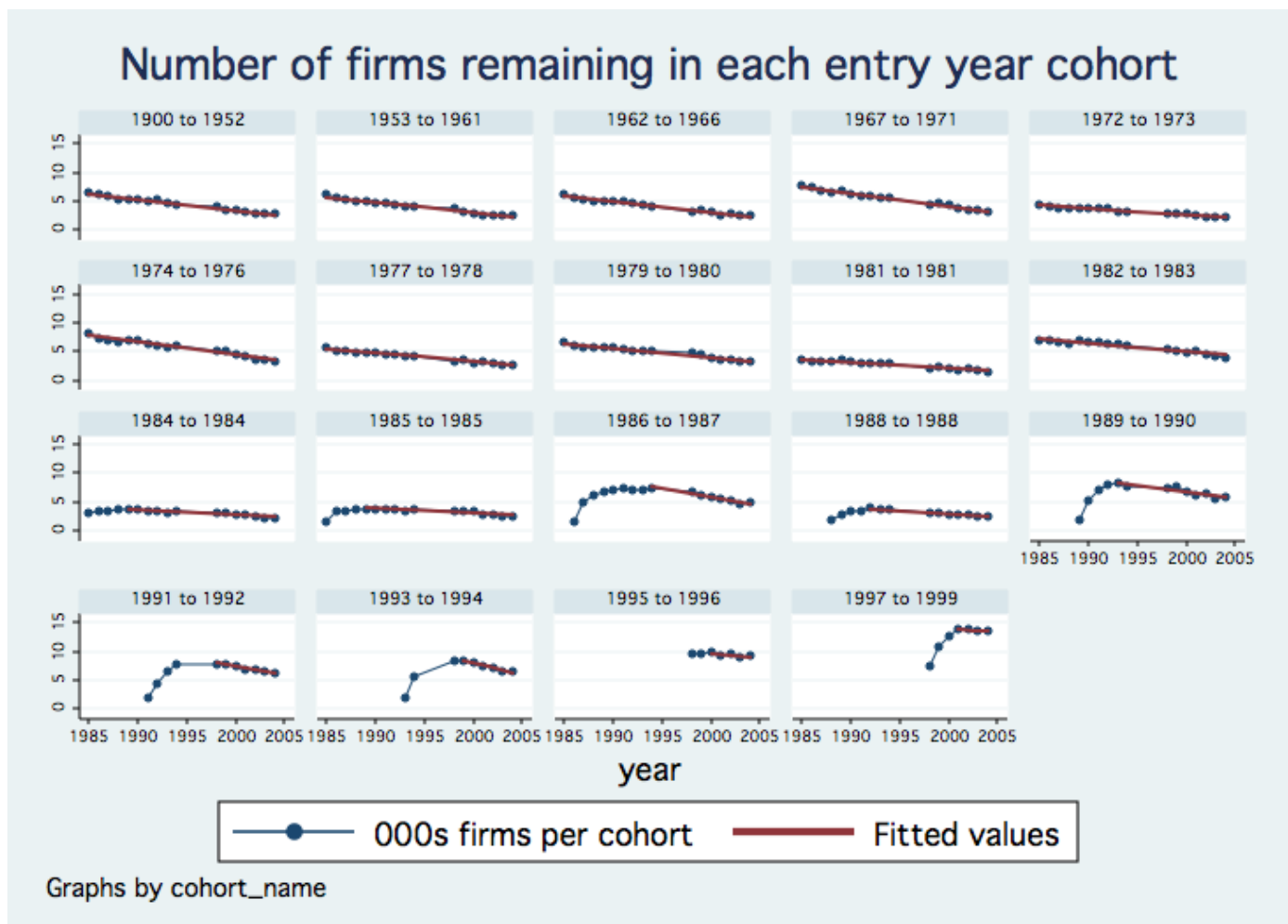

Estimated number of firms remaining in each year (in thousands), by cohort (year of initial production). Source: Authors' calculations based on Annual Survey of Industries data. 
Figure 4: Total Factor Productivity Distributions by Exit Status

(a) Years with Little False Exit

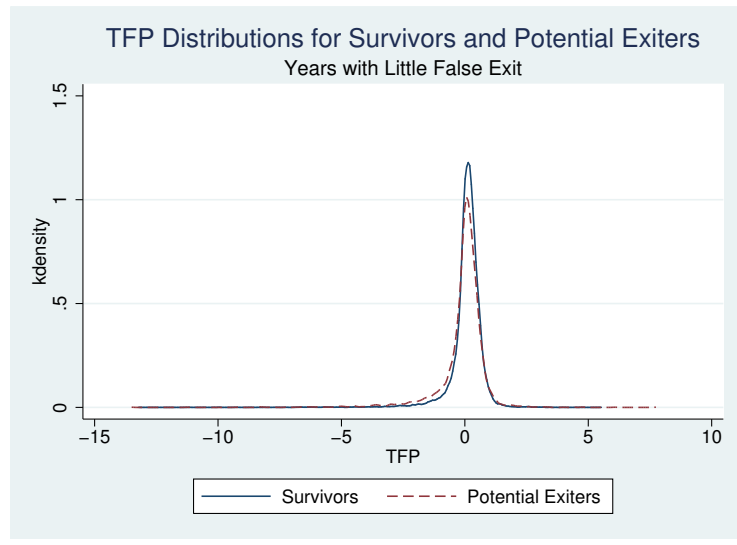

(c) Years with Little False Exit: Top and Bottom 1\% Truncated

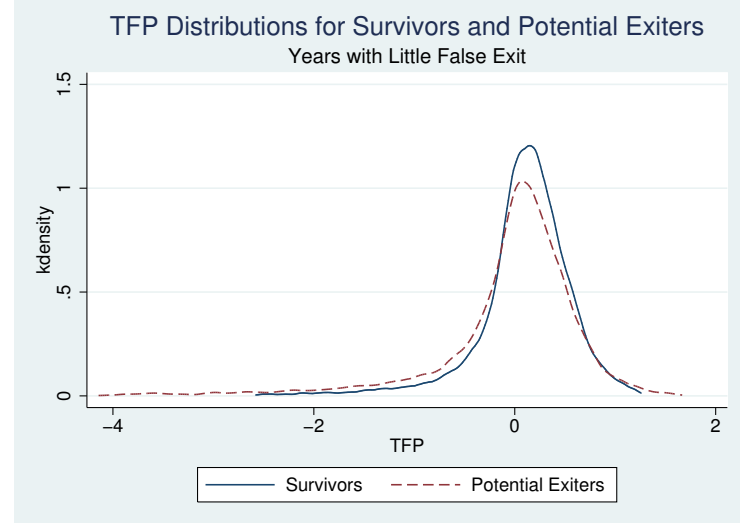

(b) Years with a Lot of False Exit

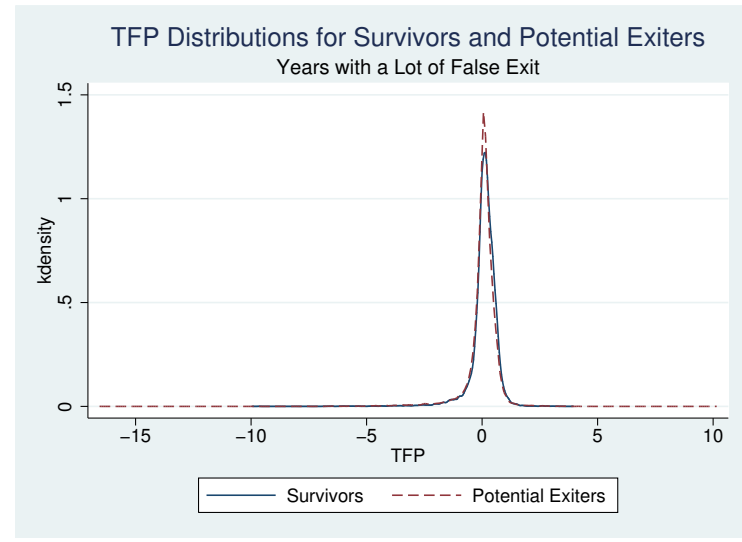

(d) Years with a Lot of False Exit: Top and Bottom $1 \%$ Truncated

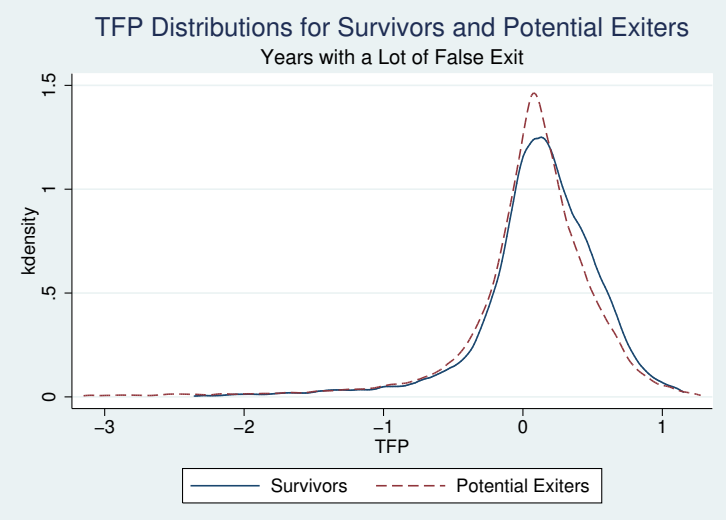

Distributions of total factor productivity (TFP) for firms identified as survivors versus potential exiters. Panel (a) shows distributions for two years (1999-2000) in which observed and predicted exit rates are similar, indicating little false exit in the panel. Panel (b) shows distributions for two years (1995 and 2004) in which observed exit rates are much higher than predicted exit rates, indicating substantial false exit in the panel. In Panels (c) and (d), the top and bottom $1 \%$ of the TFP distributions are not shown in order to focus on the parts of the distribution where most of the mass is contained. 
Figure 5: All-India Total Factor Productivity: Panel Decomposition with Baseline Exit Assumptions

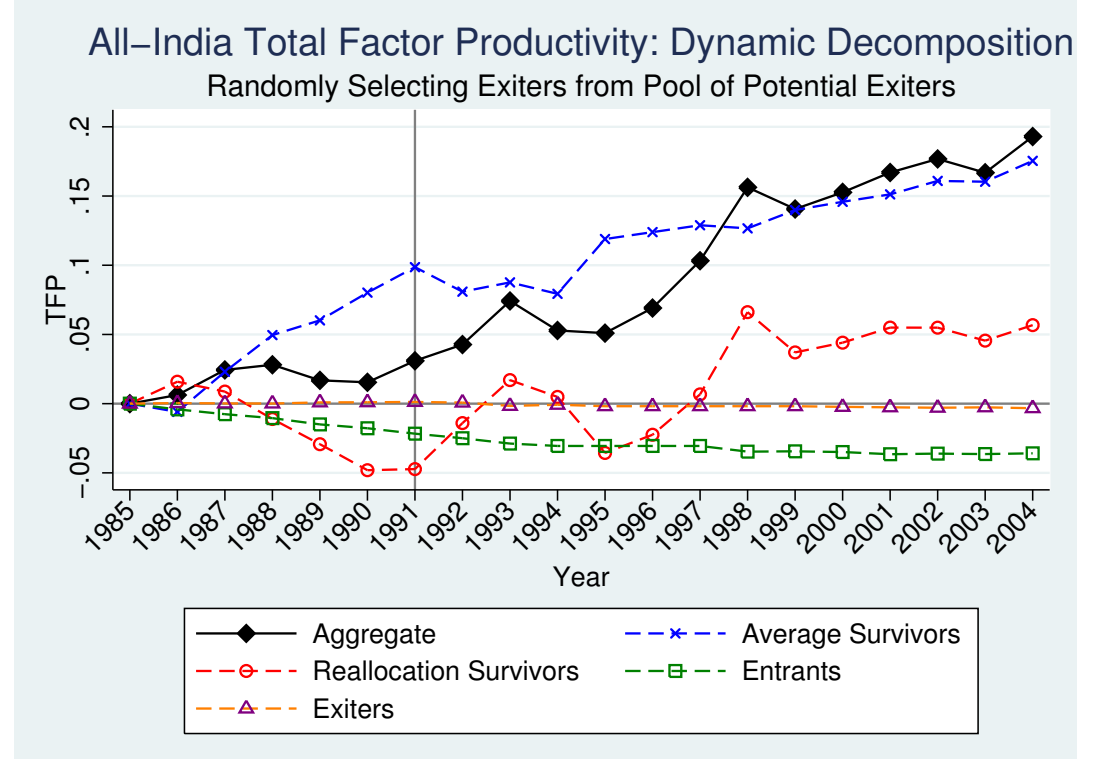

Total factor productivity (TFP) decompositions for the panel of firms, conducted at the all-India level, using the MP method. "Aggregate" indicates market-share weighted mean productivity, "Average Survivors" and "Reallocation Survivors" indicate unweighted mean productivity and the covariance between market share and productivity for surviving firms, respectively, and "Entrants" and "Exiters" indicate the contributions of entering and exiting firms. Exit is assigned randomly among the pool of potential exiters. 
Figure 6: All-India Total Factor Productivity: Sensitivity of Panel Decomposition to Different Assumptions on Exit

(a) Without Correcting for False Exit

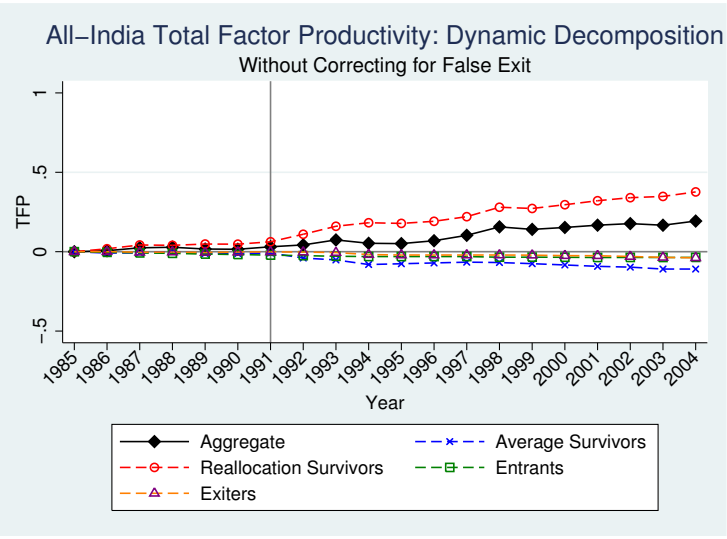

(b) Exit Assigned to Least Productive Firms

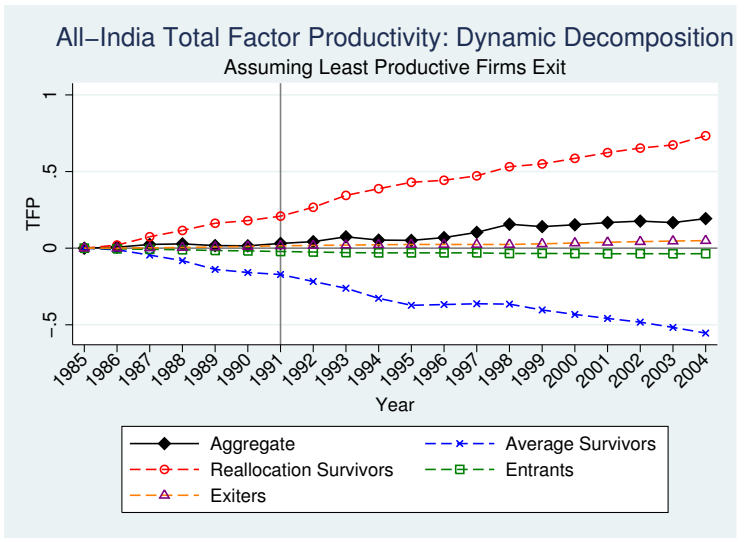

(c) Exit Assigned to Most Productive Firms

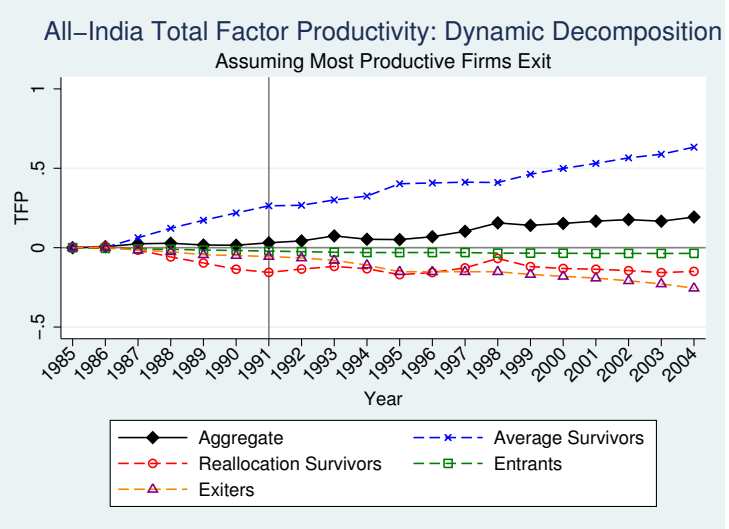

Total factor productivity (TFP) decompositions for the panel of firms, conducted at the all-India level, using the MP method. "Aggregate" indicates market-share weighted mean productivity, "Average Survivors" and "Reallocation Survivors" indicate unweighted mean productivity and the covariance between market share and productivity for surviving firms, respectively, and "Entrants" and "Exiters" indicate the contributions of entering and exiting firms. In Panel (a), we have not corrected for false exit. In Panels (b), and (c), exit is assigned among the pool of potential exiters by assuming that only the least or most productive firms exit, respectively. All graphs use the same scale to aid in comparison. 
Figure 7: State-Industry Total Factor Productivity

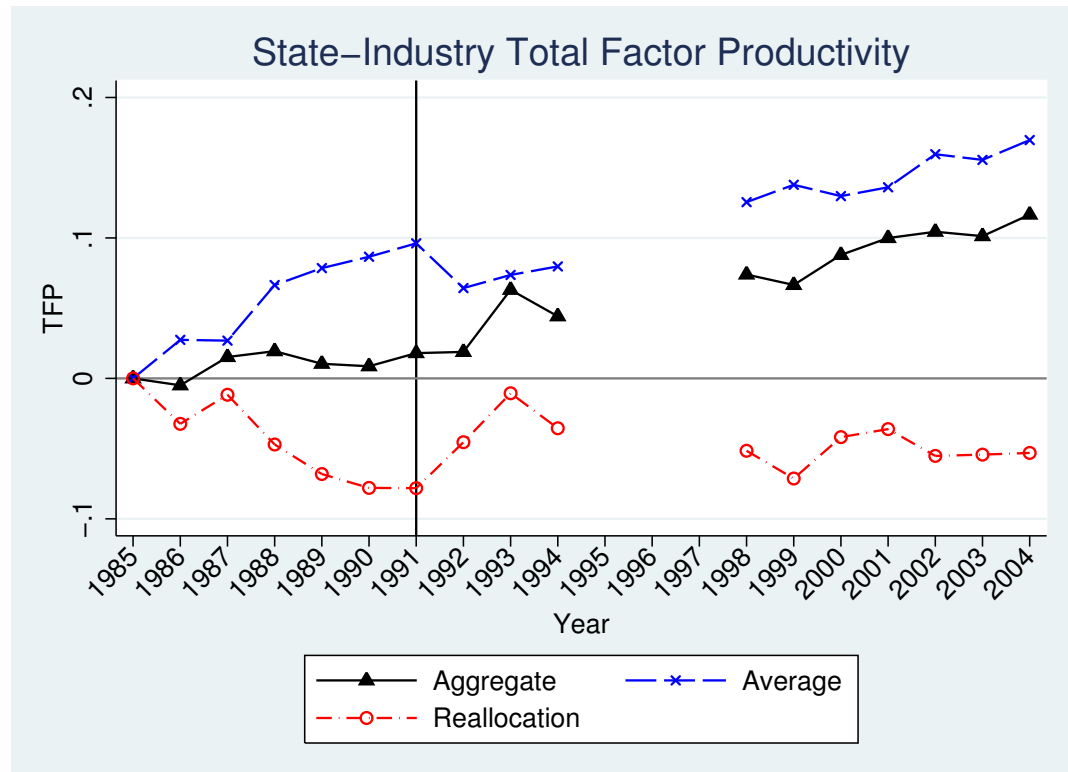

Total factor productivity (TFP) decompositions for the population of firms, conducted at the stateindustry level, using the OP method. "Aggregate" indicates market-share weighted mean productivity, "Average" indicates unweighted mean productivity, and "Reallocation" indicates the covariance between market share and productivity. Source: Authors' calculations based on Annual Survey of Industries data. 
Table 5: State-Industry Total Factor Productivity

\begin{tabular}{rrrr} 
Year & Aggregate & Average & Reallocation \\
\hline 1985 & 0.000 & 0.000 & 0.000 \\
1986 & -0.005 & 0.027 & -0.033 \\
1987 & 0.015 & 0.027 & -0.012 \\
1988 & 0.019 & 0.066 & -0.048 \\
1989 & 0.010 & 0.079 & -0.069 \\
1990 & 0.008 & 0.087 & -0.079 \\
1991 & 0.018 & 0.096 & -0.078 \\
1992 & 0.019 & 0.064 & -0.045 \\
1993 & 0.063 & 0.074 & -0.011 \\
1994 & 0.041 & 0.079 & -0.039 \\
1998 & 0.076 & 0.133 & -0.057 \\
1999 & 0.071 & 0.144 & -0.073 \\
2000 & 0.093 & 0.136 & -0.044 \\
2001 & 0.104 & 0.143 & -0.039 \\
2002 & 0.107 & 0.165 & -0.058 \\
2003 & 0.104 & 0.160 & -0.057 \\
2004 & 0.117 & 0.175 & -0.057 \\
\hline \hline
\end{tabular}

Total factor productivity (TFP) decompositions for the population of firms, conducted at the stateindustry level, using the OP method. "Aggregate" indicates market-share weighted mean productivity, "Average" indicates unweighted mean productivity, and "Reallocation" indicates the covariance between market share and productivity. Source: Authors' calculations based on Annual Survey of Industries data. 
Table 6: Productivity Decompositions and Policy Changes: Baseline Results

\begin{tabular}{lccc} 
& Aggregate & Average & Reallocation \\
\cline { 2 - 4 } & $(1)$ & $(2)$ & $(3)$ \\
\hline Final Goods Tariff & -.055 & -.044 & -.010 \\
& $(.026)^{* *}$ & $(.030)$ & $(.015)$ \\
Input Tariff & -.560 & -.556 & -.004 \\
& $(.105)^{* * *}$ & $(.115)^{* * *}$ & $(.061)$ \\
FDI Reform & .023 & .049 & -.026 \\
& $(.013)^{*}$ & $(.014)^{* * *}$ & $(.010)^{* * *}$ \\
Delicensed & -.007 & .004 & -.011 \\
& $(.017)$ & $(.017)$ & $(.011)$ \\
Obs. & 17074 & 17074 & 17074 \\
$R^{2}$ & .086 & .083 & .014 \\
\hline \hline
\end{tabular}

$\overline{\text { Each observation is a state-industry. Dependent variable names are given at the top of each column. }}$ "Aggregate" indicates market-share-weighted mean productivity, "Average" indicates unweighted mean productivity, and "Reallocation" indicates the covariance between market share and productivity. All specifications are fixed-effects analyses at the state-industry level, and include year dummies. Each observation is weighted by the total number of firms in the state-industry across all years, and standard errors are clustered at the state-industry level. 
Table 7: Productivity Decompositions and Policy Changes: MP Decomposition

\begin{tabular}{lccccc} 
& Aggregate & Avg Surv & Realloc Surv & Entrants & \multicolumn{2}{c}{ Exiters } \\
\cline { 2 - 6 } & $(1)$ & $(2)$ & $(3)$ & $(4)$ & $(5)$ \\
\hline Final Goods Tariff & -.021 & -.018 & -.004 & .001 & -.0009 \\
& $(.021)$ & $(.027)$ & $(.018)$ & $(.006)$ & $(.004)$ \\
Input Tariff & -.415 & -.501 & .070 & -.006 & .023 \\
& $(.096)^{* * *}$ & $(.114)^{* * *}$ & $(.085)$ & $(.022)$ & $(.020)$ \\
FDI Reform & .041 & .043 & -.002 & -.001 & .0009 \\
& $(.013)^{* * *}$ & $(.014)^{* * *}$ & $(.011)$ & $(.002)$ & $(.003)$ \\
Delicensed & -.008 & .004 & -.006 & .0004 & -.006 \\
& $(.015)$ & $(.018)$ & $(.017)$ & $(.004)$ & $(.008)$ \\
Obs. & 19461 & 19461 & 19461 & 19461 & 19461 \\
$R^{2}$ & .06 & .065 & .032 & .055 & .006 \\
\hline \hline
\end{tabular}

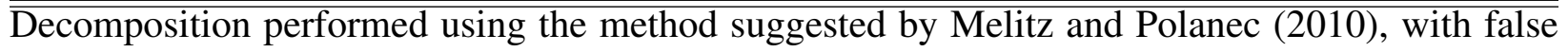
exit addressed as discussed in the text. Each observation is a state-industry. Dependent variable names are given at the top of each column. "Aggregate" indicates market-share weighted mean productivity, "Avg Surv" and "Realloc Surv" indicate unweighted mean productivity and the covariance between market share and productivity for surviving firms, respectively, and "Entrants" and "Exiters" indicate the contributions of entering and exiting firms. All specifications are fixed-effects analyses at the state-industry level, and include year dummies. Each observation is weighted by the total number of firms in the state-industry across all years, and standard errors are clustered at the state-industry level.

Table 8: Productivity Increases Implied by Policy Changes

\begin{tabular}{lcccc}
\hline & Final Goods Tariffs & Input Tariffs & FDI Liberalization & Delicensing \\
\hline Aggregate & $\mathbf{3 . 2 \%}$ & $\mathbf{2 1 . 8 \%}$ & $\mathbf{2 . 1 \%}$ & $-0.4 \%$ \\
Average & $2.6 \%$ & $\mathbf{2 1 . 7 \%}$ & $\mathbf{4 . 6 \%}$ & $0.2 \%$ \\
Reallocation & $0.6 \%$ & $0.2 \%$ & $\mathbf{- 2 . 4 \%}$ & $-0.6 \%$ \\
\hline \hline
\end{tabular}

Implied increases in aggregate, average, and reallocation productivity. Results are based on regression coefficients and average policy changes. Bold font indicates that the underlying regression results are statistically significant at the $10 \%$ level. 
Table 9: Firm-Level Productivity

\begin{tabular}{|c|c|c|c|c|}
\hline & $\frac{\text { Population }}{(1)}$ & $\begin{array}{c}\text { Panel Firms } \\
(2)\end{array}$ & $\begin{array}{c}\text { Panel Firms } \\
\text { (3) }\end{array}$ & $\begin{array}{c}\text { Firm FE } \\
(4)\end{array}$ \\
\hline Final Goods Tariff & $\begin{array}{l}.046 \\
(.026)^{*}\end{array}$ & $\begin{array}{l}.037 \\
(.019)^{*}\end{array}$ & $\begin{array}{l}-.036 \\
(.019)^{*}\end{array}$ & $\begin{array}{l}-.042 \\
(.008)^{* * *}\end{array}$ \\
\hline Input Tariff & $\begin{array}{l}-.496 \\
(.107)^{* * *}\end{array}$ & $\begin{array}{l}-.547 \\
(.087)^{* * *}\end{array}$ & $\begin{array}{l}-.537 \\
(.087)^{* * *}\end{array}$ & $\begin{array}{l}-.128 \\
(.035)^{* * *}\end{array}$ \\
\hline FDI Reform & $\begin{array}{c}.044 \\
(.015)^{* * *}\end{array}$ & $\begin{array}{c}.054 \\
(.012)^{* * * *}\end{array}$ & $\begin{array}{c}.053 \\
(.012)^{* * * *}\end{array}$ & $\begin{array}{c}.031 \\
(.004)^{* * *}\end{array}$ \\
\hline Delicensed & $\begin{array}{c}-.006 \\
(.016)\end{array}$ & $\begin{array}{r}-.003 \\
(.013)\end{array}$ & $\begin{array}{c}-.003 \\
(.013)\end{array}$ & $\begin{array}{c}-.002 \\
(.005)\end{array}$ \\
\hline Public & & & $\begin{array}{l}-.166 \\
(.014)^{* * * *}\end{array}$ & \\
\hline Young & & & $\begin{array}{l}-.093 \\
(.005)^{* * *}\end{array}$ & \\
\hline Small & & & $\begin{array}{l}-.058 \\
(.009)^{*+* *}\end{array}$ & \\
\hline Midsize & & & $\begin{array}{c}-.010 \\
(.009)\end{array}$ & \\
\hline Year FE & Yes & Yes & Yes & Yes \\
\hline Industry FE & Yes & Yes & Yes & No \\
\hline Firm FE & No & No & No & Yes \\
\hline Obs. & 1322463 & 388155 & 388155 & 388155 \\
\hline$R^{2}$ & .065 & .057 & .064 & .002 \\
\hline
\end{tabular}




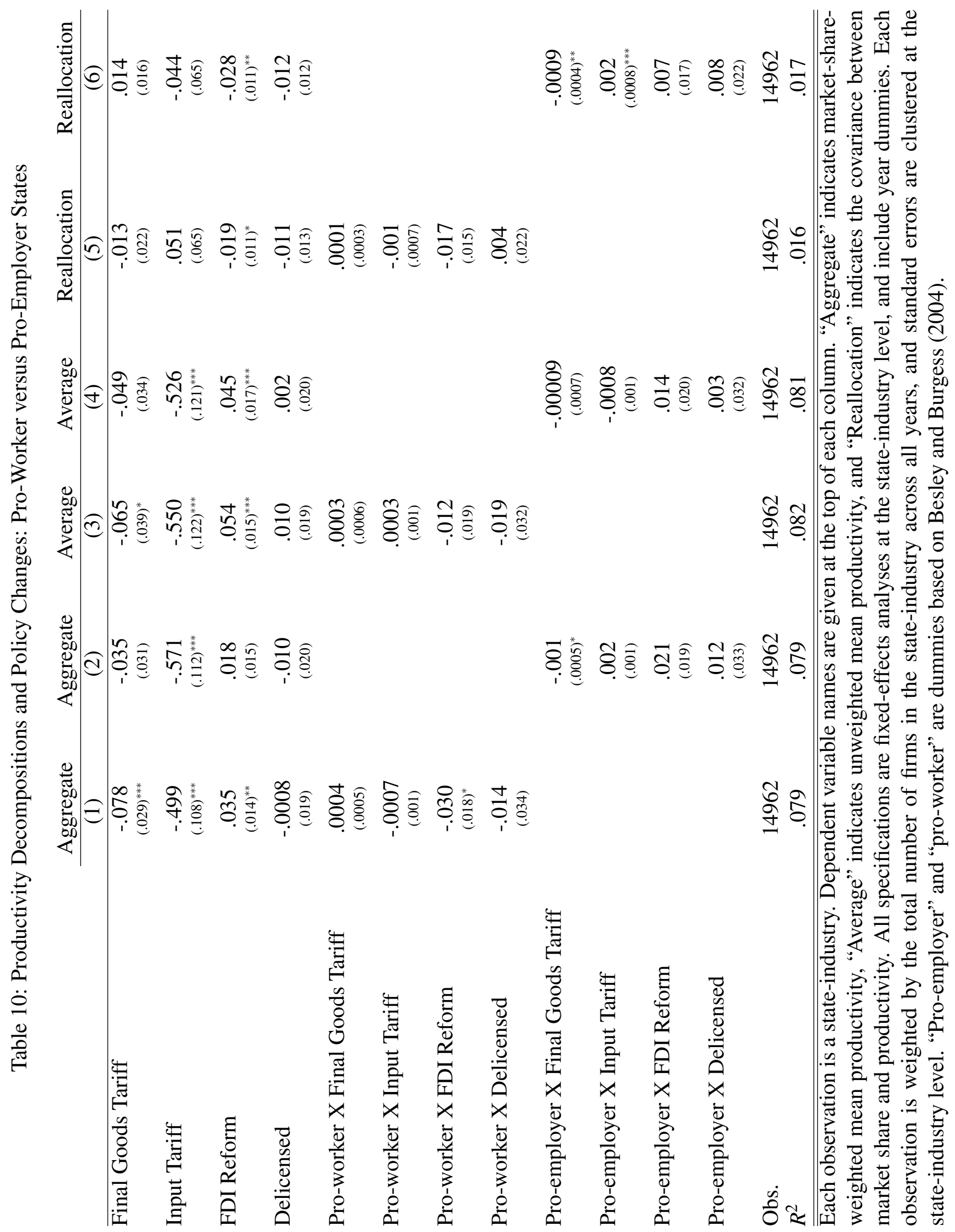




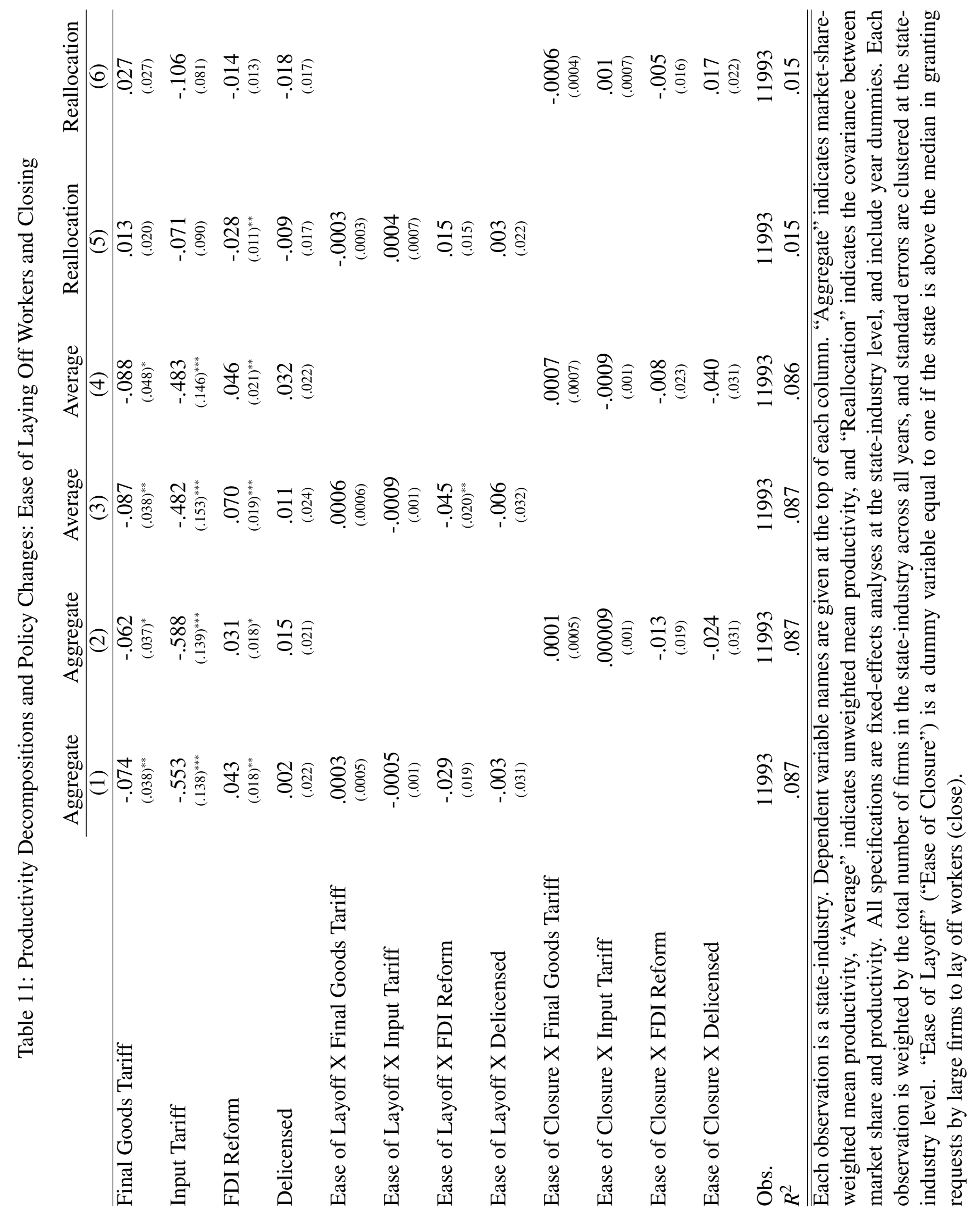




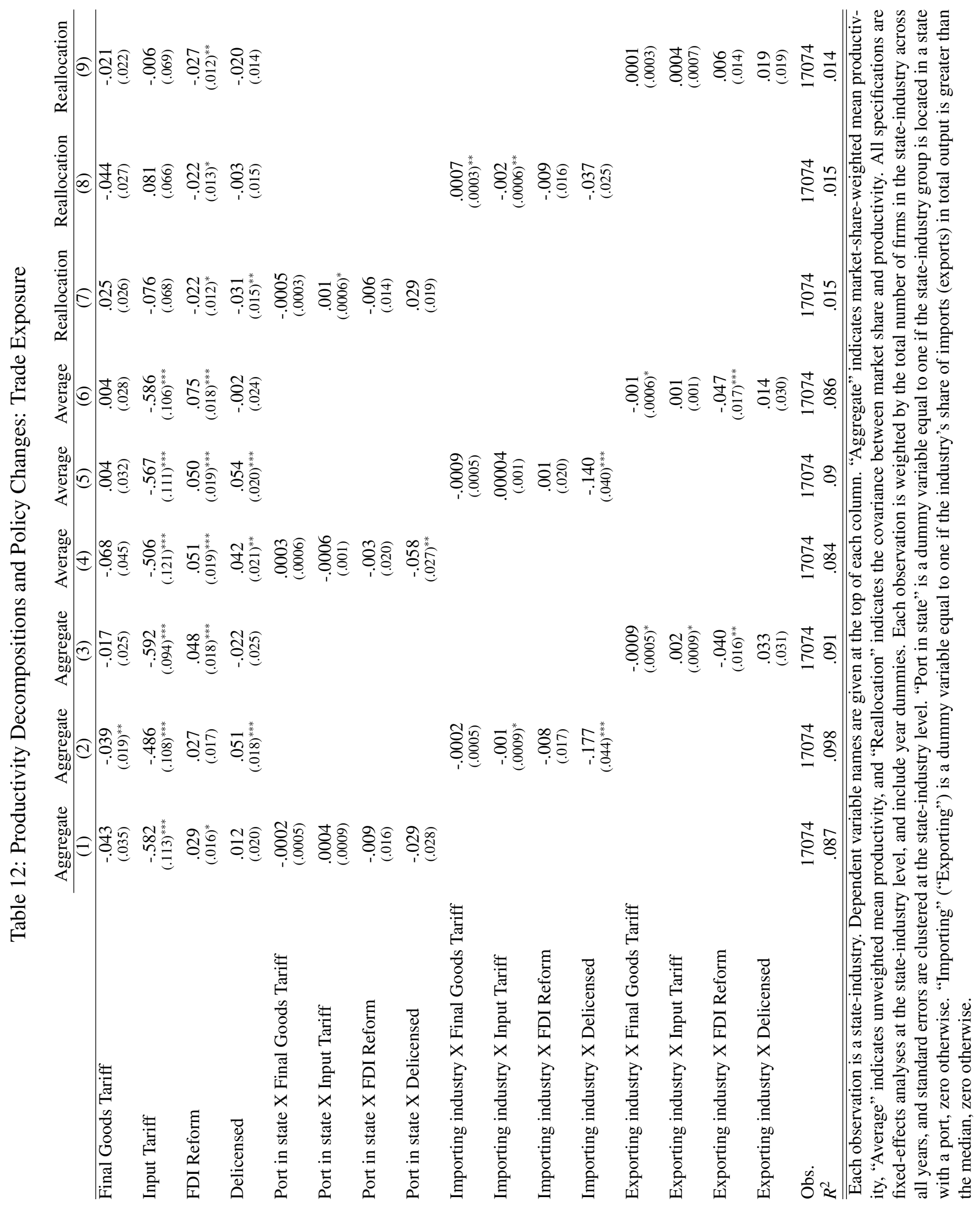


Figure 8: All-India Total Factor Productivity: By Firm Size

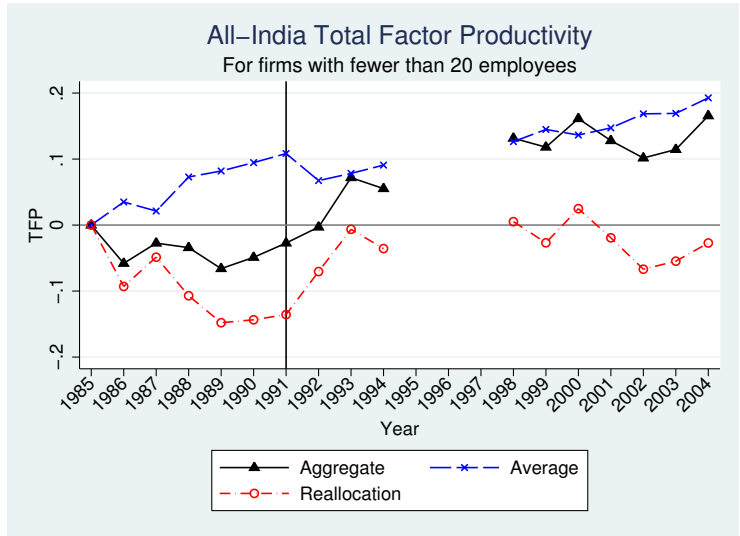

(a) Firms with Fewer than 20 Employees

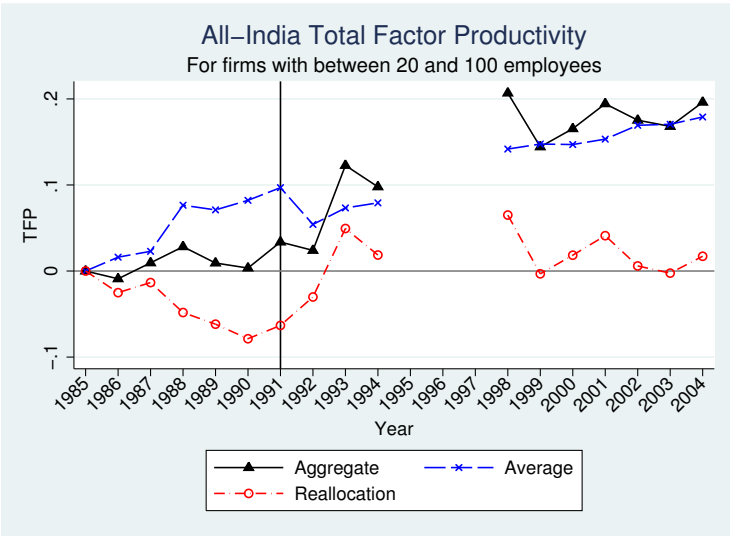

(b) Firms with 20-99 Employees

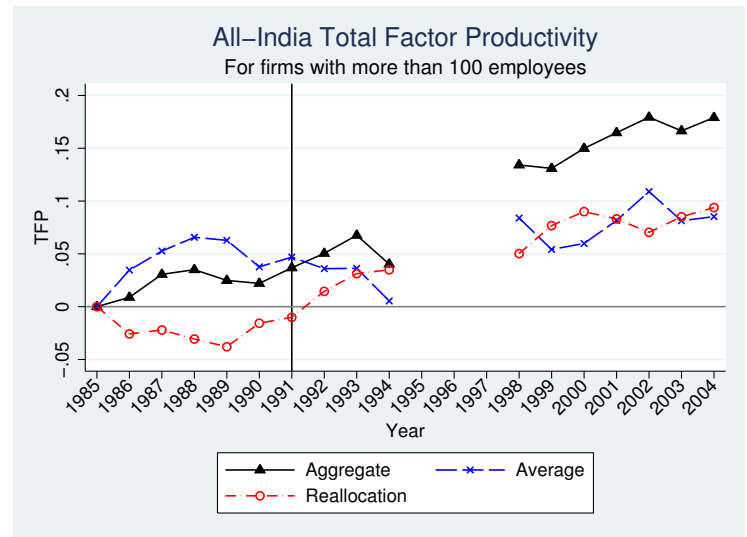

(c) Firms with 100 or More Employees

Total factor productivity (TFP) decompositions for the population of firms, divided by firm size, conducted at the state-industry level, using the OP method. "Aggregate" indicates market-share weighted mean productivity, "Average" indicates unweighted mean productivity, and "Reallocation" indicates the covariance between market share and productivity. Source: Authors' calculations based on Annual Survey of Industries data. 
Table 13: Productivity Decompositions and Policy Changes: By Firm Size

Panel A: Small Firms (<20 Employees)

\begin{tabular}{|c|c|c|c|}
\hline & $\begin{array}{c}\text { Aggregate } \\
\text { (1) }\end{array}$ & $\begin{array}{c}\text { Average } \\
\text { (2) }\end{array}$ & $\frac{\text { Reallocation }}{(3)}$ \\
\hline Final Goods Tariff & $\begin{array}{l}-.082 \\
(.036)^{* *}\end{array}$ & $\begin{array}{c}-.048 \\
(.037)\end{array}$ & $\begin{array}{l}-.034 \\
(.020)^{*}\end{array}$ \\
\hline Input Tariff & $\begin{array}{l}-.508 \\
(.159)^{* * *}\end{array}$ & $\begin{array}{l}-.426 \\
(.148)^{* * *}\end{array}$ & $\begin{array}{c}-.081 \\
(.070)\end{array}$ \\
\hline FDI Reform & $\begin{array}{l}.052 \\
(.021)^{* *}\end{array}$ & $\begin{array}{l}.038 \\
(.015)^{* *}\end{array}$ & $\begin{array}{l}.014 \\
(.014)\end{array}$ \\
\hline Delicensed & $\begin{array}{l}-.030 \\
(.022)\end{array}$ & $\begin{array}{c}-.031 \\
(.020)\end{array}$ & $\begin{array}{l}.001 \\
(.013)\end{array}$ \\
\hline $\begin{array}{l}\text { Obs. } \\
R^{2}\end{array}$ & $\begin{array}{c}10018 \\
.06\end{array}$ & $\begin{array}{c}10018 \\
.076\end{array}$ & $\begin{array}{c}10018 \\
.017\end{array}$ \\
\hline \multicolumn{4}{|c|}{ Panel B: Medium-Sized Firms (20-99 Employees) } \\
\hline Final Goods Tariff & $\begin{array}{l}-.079 \\
(.029)^{* * *}\end{array}$ & $\begin{array}{c}-.057 \\
(.039)\end{array}$ & $\begin{array}{l}-.022 \\
(.025)\end{array}$ \\
\hline Input Tariff & $\begin{array}{l}-.464 \\
(.118)^{* * *}\end{array}$ & $\begin{array}{l}-.496 \\
(.136)^{* * *}\end{array}$ & $\begin{array}{l}.032 \\
(.082)\end{array}$ \\
\hline FDI Reform & $\begin{array}{l}.024 \\
(.017)\end{array}$ & $\begin{array}{l}.032 \\
(.018)^{*}\end{array}$ & $\begin{array}{c}-.008 \\
(.012)\end{array}$ \\
\hline Delicensed & $\begin{array}{l}.025 \\
(.019)\end{array}$ & $\begin{array}{l}.036 \\
(.022)\end{array}$ & $\begin{array}{l}-.011 \\
(.015)\end{array}$ \\
\hline Obs. & 10450 & 10450 & 10450 \\
\hline$R^{2}$ & .064 & .066 & .014 \\
\hline \multicolumn{4}{|c|}{ Panel C: Large Firms (100+ Employees) } \\
\hline Final Goods Tariff & $\begin{array}{l}-.016 \\
(.033)\end{array}$ & $\begin{array}{l}-.008 \\
(.041)\end{array}$ & $\begin{array}{l}-.008 \\
(.025)\end{array}$ \\
\hline Input Tariff & $\begin{array}{l}-.627 \\
(.127)^{* * *}\end{array}$ & $\begin{array}{l}-.653 \\
(.140)^{* * *}\end{array}$ & $\begin{array}{l}.026 \\
(.085)\end{array}$ \\
\hline FDI Reform & $\begin{array}{c}.079 \\
(.025)^{* * *}\end{array}$ & $\begin{array}{l}.091 \\
(.025)^{* * *}\end{array}$ & $\begin{array}{r}-.012 \\
(.014)\end{array}$ \\
\hline Delicensed & $\begin{array}{l}.045 \\
(.025)^{*}\end{array}$ & $\begin{array}{l}.014 \\
(.025)\end{array}$ & $\begin{array}{l}.031 \\
(.019)^{*}\end{array}$ \\
\hline Obs. & 7993 & 7993 & 7993 \\
\hline$R^{2}$ & .06 & .03 & .011 \\
\hline
\end{tabular}

$\overline{\text { Each observation is a state-industry. Firms are classified into size categories based on the first }}$ year in which we observed them. Dependent variable names are given at the top of each column. "Aggregate" indicates market-share-weighted mean productivity, "Average" indicates unweighted mean productivity, and "Reallocation" indicates the covariance between market share and productivity. All specifications are fixed-effects analyses at the state-industry level, and include year dummies. Each observation is weighted by the total number of firms in the state-industry across all years, and standard errors are clustered at the state-industry level. 


\section{Appendix A: Robustness Checks}

In Tables A.1 through A.8, we present results from several robustness tests. We begin by examining our measure of productivity, which is calculated using an index number method. First, we winsorize the top and bottom $1 \%$ of the firm-level TFP values to ensure that the results are not being driven by extreme outliers. Second, we re-calculate our measure of TFP using cost shares instead of revenue shares. ${ }^{23}$ Third, we use OLS rather than an index number method to calculate TFP. Tables A.1, A.2 and A.3 indicate that the results for all of these methods are similar to the baseline results, though the effects of FDI reform are no longer statistically significant when using OLS.

Measuring capital also presents a challenge to estimating TFP. In our baseline specification, we deflated the book value of capital by the WPI for machinery. However, book values of capital may have little to do with the actual productive value of capital. Therefore, we also measure capital using the perpetual inventory method suggested by Harrison (1994) and adapted by Sivadasan (2009) for the cross-sectional setting. ${ }^{24}$ Table A.4 confirms that using this alternate measure of capital makes little difference to the coefficient estimates.

As discussed in Section 2, our analysis of the relationship between pre-reform trends in industry characteristics and reforms indicates that selection bias is unlikely to be a major factor in our results. However, we can also focus on the reforms during India's Eighth Five-Year Plan (19921997), which were largely formulated during the 1991 crisis, thus reducing the likelihood for political selection even further. In Table A.5, we present results for 1986 to 1998 only; since we are using lagged policy variables, this allows us to capture policy changes through 1997. The coefficients on final goods tariffs, input tariffs and FDI reform are somewhat smaller in magnitude than the results for the overall time period, but are qualitatively similar.

\footnotetext{
${ }^{23}$ The challenge in using cost shares is that the rental rate of capital must be estimated. If we assume that firms must borrow money in order to purchase capital, then we can use the interest rate as a proxy for the cost of capital.

${ }^{24}$ We start with the total 1985 book value of capital in industry $j$. We construct the real capital stock in each subsequent year as $K_{j t}=K_{j, t-1}[1-\delta]+I_{j t}$ where $I_{j t}$ is real investment (nominal investment deflated by the WPI for machinery in year $t$ ) and we assume a depreciation rate $(\delta)$ of $10 \%$. The capital price deflator is then given by dividing nominal capital by real capital.
} 
In Table A.6, we re-compute input tariffs using only manufacturing industries, which allows us to avoid assigning tariff rates of zero to non-traded goods, but requires us to assume that only manufacturing inputs are used in production. The results for input tariffs are substantially larger in magnitude, but qualitatively similar, to the baseline results.

Next, we remove the two industries (the blending of spirits and the production of wine) for which the tariff reforms did not fit the pattern shown in Figure 1. In Table A.7, we show that the results are robust to excluding these two industries. Finally, as discussed in Section 4, we weight our baseline results by the total number of firms in a state-industry group over all years. Table A.8 shows that most of the results are similar when we place an equal weight on each state-industry.

Table A.1: Productivity Decompositions and Policy Changes: Winsorized Productivity

\begin{tabular}{|c|c|c|c|}
\hline & $\frac{\text { Aggregate }}{(1)}$ & $\frac{\text { Average }}{(2)}$ & $\frac{\text { Reallocation }}{(3)}$ \\
\hline Final Goods Tariff & $\begin{array}{l}-.053 \\
(.025)^{* *}\end{array}$ & $\begin{array}{c}-.047 \\
(.028)\end{array}$ & $\begin{array}{c}-.007 \\
(.013)\end{array}$ \\
\hline Input Tariff & $\begin{array}{l}-.549 \\
(.099)^{* * *}\end{array}$ & $\begin{array}{l}-.546 \\
(.109)^{* * *}\end{array}$ & $\begin{array}{c}-.003 \\
(.053)\end{array}$ \\
\hline FDI Reform & $\begin{array}{l}.030 \\
(.011)^{* * *}\end{array}$ & $\begin{array}{l}.049 \\
(.013)^{* * *}\end{array}$ & $\begin{array}{l}-.019 \\
(.008)^{* *}\end{array}$ \\
\hline Delicensed & $\begin{array}{c}-.008 \\
(.016)\end{array}$ & $\begin{array}{l}.002 \\
(.016)\end{array}$ & $\begin{array}{l}-.010 \\
(.009)\end{array}$ \\
\hline Obs. & 17074 & 17074 & 17074 \\
\hline$R^{2}$ & .119 & .11 & .016 \\
\hline
\end{tabular}

$\overline{\text { Each observation is a state-industry. Dependent variable names are given at the top of each column. }}$ "Aggregate" indicates market-share-weighted mean productivity, "Average" indicates unweighted mean productivity, and "Reallocation" indicates the covariance between market share and productivity. All specifications are fixed-effects analyses at the state-industry level, and include year dummies. Each observation is weighted by the total number of firms in the state-industry across all years, and standard errors are clustered at the state-industry level. The top and bottom $1 \%$ of TFP have been winsorized. 
Table A.2: Productivity Decompositions and Policy Changes: Cost Shares Productivity

\begin{tabular}{|c|c|c|c|}
\hline & $\frac{\text { Aggregate }}{(1)}$ & $\begin{array}{c}\text { Average } \\
\text { (2) }\end{array}$ & $\frac{\text { Reallocation }}{\text { (3) }}$ \\
\hline Final Goods Tariff & $\begin{array}{l}-.055 \\
(.025)^{* *}\end{array}$ & $\begin{array}{c}-.045 \\
(.028)\end{array}$ & $\begin{array}{c}-.010 \\
(.016)\end{array}$ \\
\hline Input Tariff & $\begin{array}{l}-.553 \\
(.099)^{* * *}\end{array}$ & $\begin{array}{l}-.542 \\
(.107)^{* * *}\end{array}$ & $\begin{array}{c}-.011 \\
(.059)\end{array}$ \\
\hline FDI Reform & $\begin{array}{l}-.001 \\
(.010)\end{array}$ & $\begin{array}{l}.023 \\
(.010)^{* *}\end{array}$ & $\begin{array}{l}-.024 \\
(.008)^{* * *}\end{array}$ \\
\hline Delicensed & $\begin{array}{l}-.002 \\
(.015)\end{array}$ & $\begin{array}{l}.003 \\
(.016)\end{array}$ & $\begin{array}{c}-.004 \\
(.011)\end{array}$ \\
\hline $\begin{array}{l}\text { Obs. } \\
R^{2}\end{array}$ & $\begin{array}{c}17074 \\
.193\end{array}$ & $\begin{array}{c}17074 \\
.158\end{array}$ & $\begin{array}{c}17074 \\
.013\end{array}$ \\
\hline
\end{tabular}

$\overline{\text { Each observation is a state-industry. Dependent variable names are given at the top of each column. }}$

"Aggregate" indicates market-share-weighted mean productivity, "Average" indicates unweighted mean productivity, and "Reallocation" indicates the covariance between market share and productivity. All specifications are fixed-effects analyses at the state-industry level, and include year dummies. Each observation is weighted by the total number of firms in the state-industry across all years, and standard errors are clustered at the state-industry level. TFP is estimated using a chain-linked index number method, where input shares are calculated as the share of input cost in total cost. 
Table A.3: Productivity Decompositions and Policy Changes: OLS Productivity

\begin{tabular}{|c|c|c|c|}
\hline & $\frac{\text { Aggregate }}{(1)}$ & $\begin{array}{c}\text { Average } \\
\text { (2) }\end{array}$ & $\frac{\text { Reallocation }}{\text { (3) }}$ \\
\hline Final Goods Tariff & $\begin{array}{l}-.063 \\
(.024)^{* * *}\end{array}$ & $\begin{array}{l}-.058 \\
(.026)^{* *}\end{array}$ & $\begin{array}{l}-.006 \\
(.012)\end{array}$ \\
\hline Input Tariff & $\begin{array}{l}-.473 \\
(.095)^{* * *}\end{array}$ & $\begin{array}{l}-.413 \\
(.102)^{* * *}\end{array}$ & $\begin{array}{l}-.059 \\
(.053)\end{array}$ \\
\hline FDI Reform & $\begin{array}{c}-.001 \\
(.010)\end{array}$ & $\begin{array}{l}.011 \\
(.009)\end{array}$ & $\begin{array}{l}-.013 \\
(.007)^{*}\end{array}$ \\
\hline Delicensed & $\begin{array}{c}-.009 \\
(.014)\end{array}$ & $\begin{array}{l}.011 \\
(.015)\end{array}$ & $\begin{array}{l}-.020 \\
(.010)^{* *}\end{array}$ \\
\hline Obs. & 17074 & 17074 & 17074 \\
\hline$R^{2}$ & .133 & .166 & .021 \\
\hline
\end{tabular}

$\overline{\text { Each observation is a state-industry. Dependent variable names are given at the top of each column. }}$

"Aggregate" indicates market-share-weighted mean productivity, "Average" indicates unweighted mean productivity, and "Reallocation" indicates the covariance between market share and productivity. All specifications are fixed-effects analyses at the state-industry level, and include year dummies. Each observation is weighted by the total number of firms in the state-industry across all years, and standard errors are clustered at the state-industry level. TFP is estimated using OLS. 
Table A.4: Productivity Decompositions and Policy Changes: Alternative Measure of Capital

\begin{tabular}{lccc} 
& Aggregate & Average & Reallocation \\
\cline { 2 - 4 } & $(1)$ & $(2)$ & $(3)$ \\
\hline Final Goods Tariff & -.049 & -.039 & -.010 \\
\multirow{2}{*}{ Input Tariff } & $(.025)^{*}$ & $(.030)$ & $(.015)$ \\
& -.498 & -.494 & -.004 \\
FDI Reform & $(.104)^{* * *}$ & $(.115)^{* * *}$ & $(.061)$ \\
& .015 & .040 & -.026 \\
Delicensed & $(.013)$ & $(.013)^{* * *}$ & $(.010)^{* * *}$ \\
& -.006 & .005 & -.011 \\
Obs. & $(.016)$ & $(.016)$ & $(.011)$ \\
$R^{2}$ & 17074 & 17074 & 17074 \\
\hline Each observation is a state-industry. Dependent variable names are given at the top of each column.
\end{tabular}

"Aggregate" indicates market-share-weighted mean productivity, "Average" indicates unweighted mean productivity, and "Reallocation" indicates the covariance between market share and productivity. All specifications are fixed-effects analyses at the state-industry level, and include year dummies. Each observation is weighted by the total number of firms in the state-industry across all years, and standard errors are clustered at the state-industry level. An alternative method of deflating capital, based on the perpetual inventory method of Harrison (1994), as modified by Sivadasan (2009), is used. 
Table A.5: Productivity Decompositions and Policy Changes: 1986- 1998

\begin{tabular}{|c|c|c|c|}
\hline & $\frac{\text { Aggregate }}{\text { (1) }}$ & $\frac{\text { Average }}{(2)}$ & $\frac{\text { Reallocation }}{(3)}$ \\
\hline Final Goods Tariff & $\begin{array}{l}-.039 \\
(.021)^{*}\end{array}$ & $\begin{array}{l}-.041 \\
(.023)^{*}\end{array}$ & $\begin{array}{l}.001 \\
(.015)\end{array}$ \\
\hline Input Tariff & $\begin{array}{l}-.250 \\
(.109)^{* *}\end{array}$ & $\begin{array}{l}-.268 \\
(.104)^{* * *}\end{array}$ & $\begin{array}{l}.018 \\
(.074)\end{array}$ \\
\hline FDI Reform & $\begin{array}{l}.022 \\
(.014)\end{array}$ & $\begin{array}{c}.034 \\
(.011)^{* * *}\end{array}$ & $\begin{array}{c}-.012 \\
(.012)\end{array}$ \\
\hline Delicensed & $\begin{array}{c}-.0001 \\
(.014)\end{array}$ & $\begin{array}{c}-.003 \\
(.011)\end{array}$ & $\begin{array}{l}.003 \\
(.012)\end{array}$ \\
\hline $\begin{array}{l}\text { Obs. } \\
R^{2}\end{array}$ & $\begin{array}{c}10666 \\
.034\end{array}$ & $\begin{array}{c}10666 \\
.045\end{array}$ & $\begin{array}{c}10666 \\
.019\end{array}$ \\
\hline
\end{tabular}

$\overline{\text { Each observation is a state-industry. Dependent variable names are given at the top of each column. }}$ "Aggregate" indicates market-share-weighted mean productivity, "Average" indicates unweighted mean productivity, and "Reallocation" indicates the covariance between market share and productivity. All specifications are fixed-effects analyses at the state-industry level, and include year dummies. Each observation is weighted by the total number of firms in the state-industry across all years, and standard errors are clustered at the state-industry level. Only firm-level data from 1986 to 1998 (policy variables from 1985 to 1997) are included. 
Table A.6: Productivity Decompositions and Policy Changes: Alternative Measure of Input Tariffs

\begin{tabular}{|c|c|c|c|}
\hline & $\frac{\text { Aggregate }}{(1)}$ & $\frac{\text { Average }}{(2)}$ & $\frac{\text { Reallocation }}{(3)}$ \\
\hline Final Goods Tariff & $\begin{array}{l}.010 \\
(.016)\end{array}$ & $\begin{array}{l}.035 \\
(.024)\end{array}$ & $\begin{array}{c}-.025 \\
(.019)\end{array}$ \\
\hline Input Tariff, 1 year lag & $\begin{array}{l}-.900 \\
(.110)^{* * *}\end{array}$ & $\begin{array}{l}-.991 \\
(.108)^{* * *}\end{array}$ & $\begin{array}{l}.091 \\
(.061)\end{array}$ \\
\hline FDI Reform & $\begin{array}{l}.019 \\
(.013)\end{array}$ & $\begin{array}{c}.043 \\
(.014)^{* * *}\end{array}$ & $\begin{array}{l}-.025 \\
(.009)^{* * *}\end{array}$ \\
\hline Delicensed & $\begin{array}{c}-.015 \\
(.016)\end{array}$ & $\begin{array}{c}-.003 \\
(.015)\end{array}$ & $\begin{array}{c}-.012 \\
(.011)\end{array}$ \\
\hline $\begin{array}{l}\text { Obs. } \\
R^{2}\end{array}$ & $\begin{array}{c}17074 \\
.105\end{array}$ & $\begin{array}{l}17074 \\
.104\end{array}$ & $\begin{array}{c}17074 \\
.014\end{array}$ \\
\hline
\end{tabular}

$\overline{\text { Each observation is a state-industry. Dependent variable names are given at the top of each column. }}$ "Aggregate" indicates market-share-weighted mean productivity, "Average" indicates unweighted mean productivity, and "Reallocation" indicates the covariance between market share and productivity. All specifications are fixed-effects analyses at the state-industry level, and include year dummies. Each observation is weighted by the total number of firms in the state-industry across all years, and standard errors are clustered at the state-industry level. Input tariffs are constructed based on the manufacturing sector only. 
Table A.7: Productivity Decompositions and Policy Changes: Removing Outlying Tariff Changes

\begin{tabular}{|c|c|c|c|}
\hline & $\frac{\text { Aggregate }}{\text { (1) }}$ & $\frac{\text { Average }}{(2)}$ & $\frac{\text { Reallocation }}{\text { (3) }}$ \\
\hline Final Goods Tariff & $\begin{array}{l}-.057 \\
(.026)^{* *}\end{array}$ & $\begin{array}{l}-.046 \\
(.030)\end{array}$ & $\begin{array}{l}-.011 \\
(.015)\end{array}$ \\
\hline Input Tariff & $\begin{array}{l}-.552 \\
(.105)^{* * *}\end{array}$ & $\begin{array}{l}-.549 \\
(.115)^{* * *}\end{array}$ & $\begin{array}{c}-.003 \\
(.061)\end{array}$ \\
\hline FDI Reform & $\begin{array}{l}.022 \\
(.014)\end{array}$ & $\begin{array}{l}.047 \\
(.014)^{* * *}\end{array}$ & $\begin{array}{l}-.026 \\
(.010)^{* * *}\end{array}$ \\
\hline Delicensed & $\begin{array}{c}-.008 \\
(.017)\end{array}$ & $\begin{array}{l}.003 \\
(.017)\end{array}$ & $\begin{array}{c}-.011 \\
(.011)\end{array}$ \\
\hline $\begin{array}{l}\text { Obs. } \\
R^{2}\end{array}$ & $\begin{array}{c}16898 \\
.087\end{array}$ & $\begin{array}{c}16898 \\
.083\end{array}$ & $\begin{array}{c}16898 \\
.014\end{array}$ \\
\hline
\end{tabular}

$\overline{\text { Each observation is a state-industry. Dependent variable names are given at the top of each column. }}$ "Aggregate" indicates market-share-weighted mean productivity, "Average" indicates unweighted mean productivity, and "Reallocation" indicates the covariance between market share and productivity. All specifications are fixed-effects analyses at the state-industry level, and include year dummies. Each observation is weighted by the total number of firms in the state-industry across all years, and standard errors are clustered at the state-industry level. The two industries that do not fit the overall pattern shown in Figure 1 are excluded. 
Table A.8: Productivity Decompositions and Policy Changes: Without State-Industry Weights

\begin{tabular}{|c|c|c|c|}
\hline & $\frac{\text { Aggregate }}{(1)}$ & $\frac{\text { Average }}{(2)}$ & $\frac{\text { Reallocation }}{\text { (3) }}$ \\
\hline Final Goods Tariff & $\begin{array}{l}-.059 \\
(.018)^{* * *}\end{array}$ & $\begin{array}{l}-.050 \\
(.020)^{* *}\end{array}$ & $\begin{array}{l}-.009 \\
(.015)\end{array}$ \\
\hline Input Tariff & $\begin{array}{l}-.713 \\
(.089)^{* * *}\end{array}$ & $\begin{array}{l}-.674 \\
(.098)^{* * *}\end{array}$ & $\begin{array}{c}-.039 \\
(.064)\end{array}$ \\
\hline FDI Reform & $\begin{array}{l}.049 \\
(.011)^{* * *}\end{array}$ & $\begin{array}{l}.069 \\
(.012)^{* * *}\end{array}$ & $\begin{array}{l}-.020 \\
(.009)^{* *}\end{array}$ \\
\hline Delicensed & $\begin{array}{l}-.026 \\
(.012)^{* *}\end{array}$ & $\begin{array}{l}-.023 \\
(.013)^{*}\end{array}$ & $\begin{array}{c}-.003 \\
(.010)\end{array}$ \\
\hline $\begin{array}{l}\text { Obs. } \\
R^{2}\end{array}$ & $\begin{array}{c}17074 \\
.056\end{array}$ & $\begin{array}{c}17074 \\
.048\end{array}$ & $\begin{array}{c}17074 \\
.003\end{array}$ \\
\hline
\end{tabular}

$\overline{\text { Each observation is a state-industry. Dependent variable names are given at the top of each column. }}$

"Aggregate" indicates market-share-weighted mean productivity, "Average" indicates unweighted mean productivity, and "Reallocation" indicates the covariance between market share and productivity. All specifications are fixed-effects analyses at the state-industry level, and include year dummies. Each observation is given equal weight, and standard errors are clustered at the stateindustry level. 